\title{
Porifera (sponges) of the Dampier Archipelago, Western Australia: habitats and distributions
}

\author{
Jane Fromont \\ Department of Aquatic Zoology (Marine Invertebrates), Western Australian Museum, \\ Francis Street, Perth, Western Australia 6000, Australia \\ email: jane fromont@museum.wa.gov.au
}

\begin{abstract}
This study reports on 221 species of sponges collected during two diving expeditions to the archipelago in 1998 and 1999. A further 32 species were collected from a dredge survey in 1999 and another 22 during a residential workshop in the region in 2000. The total number of species (275) reported here indicates a high sponge species richness in the Dampier Archipelago. Previsously, only 14 species of Porifera have been reported from the Dampier Archipelago, north-western Australia.
\end{abstract}

\section{INTRODUCTION}

The Dampier Archipelago lies between $20^{\circ} 20$ $20^{\circ} 45^{\prime} \mathrm{S}, 116^{\circ} 25-117^{\circ} 05^{\prime} \mathrm{E}$, in the north-west of Australia. Within the region are 42 islands, islets and rock outcrops that became remnant dry land $6000-8000$ years ago when sea levels fell. The study area was shallow, defined by the $30 \mathrm{~m}$ depth contour with only one location, Madeleine Shoals, sampled to seaward of this. The climate is tropical but semi-arid with an unreliable, seasonal rainfall. No major river systems drain into the region. A wide range of exposures occur throughout the archipelago, with outer islands with clear waters most exposed to wave action, inshore bays moderately sheltered by islands, to protected waters that can become extremely turbid. Large tidal amplitudes occur in the archipelago with a maximum range of $5.1 \mathrm{~m}$ (Jones, 2004). The marine habitats of the islands are diverse consisting of mangrove, extensive intertidal flats, rocky shores and beaches, subtidal rocky reefs, coral reefs, silty plains and limestone pavements.

Prior to the fieldwork reported upon here, the documented sponge fauna of the region amounted to 14 species (Table 1). This lack of scientific knowledge about a prevalent sessile fauna and the availability of a sponge specialist, prompted the Western Australian Museum to include Porifera in collections during a series of expeditions to the region. This work constitutes part of a wider study to document the marine flora and fauna of the Dampier Archipelago.

Two of the expeditions (DA1/98 and DA3/99) and a workshop (DA4/00) included SCUBA diving and intertidal collections. There was one dredging expedition (DA2/99). The first diving expedition (DA1/98) was undertaken in October 1998, the second (DA3/99) in August-September 1999 and the workshop (DA4/00) in July-August 2000. The dredging expedition (DA2/99) was undertaken in July 1999.

Three complementary publications have been produced on the sponge fauna of the archipelago. In this publication, detailed habitat descriptions and distributions of the sponges are provided. A second paper examines the taxonomic and biogeographical affinities of the sponge fauna and compares it to other tropical regions (Fromont, 2003) and species distributions and abundances are currently being analysed (Fromont et al. in prep.).

\section{MATERIALS AND METHODS}

A total of 34 stations was sampled for sponges in the northeastern region of the Dampier Archipelago from 17-29 October 1998 (DA1/98). Twelve of these stations were intertidal and 22 were subtidal at depths ranging between $0.8-22.0 \mathrm{~m}$. A total of 35 stations was sampled in the southern region of the archipelago from 27 August to 8 September 1999 (DA3/99). Nine of these stations were intertidal and 26 were subtidal at depths ranging between 3.6$17.6 \mathrm{~m}$. Seventeen stations were sampled for sponges throughout the archipelago from 25 July to 3 August 2000 during the workshop conducted in the region (DA4/00). Of these stations, three were intertidal and the remaining 14 were subtidal at depths ranging between 4-20 m. All 100 stations of the dredging expedition (DA2/99) were subtidal and many were at deeper depths than those targeted during the diving and workshop expeditions. Depths of dredging stations were between $5-43 \mathrm{~m}$.

Methods of collection included reef walks at the 
intertidal sites, a snorkel dive and all remaining dives on SCUBA. At the intertidal localities, sponges were collected by moving in a wide swathe from the water's edge to the top of the beach or vice versa depending on the phase of the tide. Subtidal stations were sampled by collecting into the current for the first half of the dive and collecting with the current for the last part of the dive but over different ground. At all diving and workshop stations, a specimen of each sponge species was collected if it had not already been sampled. Specimens were also taken of previously collected species if there were morphological or colour differences, or if the habitat was different from previous localities for that particular species.

Specimens were separated immediately in situ to avoid contamination by mucous exudation from other sponges, or possible spicule loss. After collection, records were made of natural colour, changes in coloration on exposure to air, mucous exudation and gross morphology and habitat, for each specimen collected. Specimens were stored individually in 70\% ethanol. Many individuals were photographed in situ or on deck. All sponge collections on the diving fieldtrips and workshop were undertaken by the author.

Methods on the dredging expedition (DA2/99) differed from those on the diving expeditions and workshop, with collecting done by dredge or grab. Dredge tows were for 10 minutes at a speed of 2-3 knots. The dredge was $1200 \times 330 \mathrm{~cm}$ and the mesh size $1 \mathrm{~cm}$, except for eight stations where a finer mesh was added. Sponges were collected by Melissa Hewitt and Shirley Slack-Smith of the W.A. Museum. Deck photographs were taken where possible and sponges were preserved in ethanol as above. Because of time constraints only a subset of sponges collected during this expedition were retained.

Spicule preparations and skeletal slides were made for each specimen (Fromont, 1998). Final identifications, station details and collector have been entered onto the Marine Invertebrates database.

\section{RESULTS}

One hundred and seventy-two sponge species were collected from the 34 stations examined in the first diving expedition (DA1/98) and 132 sponge species were collected from the 35 stations examined in the second diving expedition (DA3/ 99) (Appendix 1). Forty-nine of these species had not been collected on the first diving expedition and 89 species collected on the first were not recollected on the second. Eighty-three species were common to both surveys. Latitudes and longitudes of each station and a map of their locations are provided in Appendices 2 and 3.

Seventy-six sponge species were collected from
31 stations on the dredging expedition DA2/99 (Appendix 4). No sponges were reported from 27 stations in this expedition and an additional six stations (DA2/99/11, 14, 80, 86, 97 and 100) specifically targeted soft sediments and the catch was not examined for sponges. Sponges were reported to be present at the remaining 26 stations but no specimens were collected. Thirty-two of the species collected on this expedition had not been collected on the diving surveys and a further 22 , that had not been collected previously, were collected during the DA4/00 workshop expedition (Appendix 5). Latitudes and longitudes of each station and a map of their locations are given in Appendices 6-9.

Examination of the numbers of species collected from each station indicated that those with highest species numbers ( $>20$ per station) were four intertidal stations (DA1/98/17, 23, 28, 31) in the northeastern region of the archipelago, one subtidal station at $8 \mathrm{~m}$ depth in the north-east (DA1/98/33), and eight subtidal stations both in the north-east and south of the archipelago between $9.0-17.6 \mathrm{~m}$ depth (DA1/98 /04, 15, 27, 32; DA3/99/55, 56, 65; DA2/99/37). The most species rich station was DA3/99/65 at $14 \mathrm{~m}$ depth in the south of the archipelago with 43 species.

Comprehensive habitat descriptions were documented for all stations on the two diving expeditions and as many different habitat types as possible were sampled on these field trips, thus allowing for detailed comparisons of species richness and habitat type to be attempted. These results are outlined below. The dredging and workshop data are incorporated into the discussion.

\section{DA1/98 and DA3/99 diving expeditions}

\section{Intertidal stations}

Twenty-one intertidal stations were sampled during the two diving expeditions (DA1/98 and DA3/99). The intertidal stations most depauperate in sponge species ( $<5$ species) were DA1/98/05 and DA3/99/62 (2 species), DA1/98/07 (3 species) and DA3/99/59 (4 species). Stations DA1/98/05 and DA3/99/62 were oyster dominated areas whilst stations DA1/98/07 and DA3/99/59 consisted predominantly of igneous boulders (Table 2).

Seven intertidal stations had between 5 and 10 species (Table 2). These were stations DA3/99/48 (6 species), DA3/99/66 (7 species), DA1/98/02, DA1/98/25 and DA3/99/45 (8 species), DA1/98/ 14 (9 species) and DA3/99/38 (10 species). These stations consisted of shallow channels, creeks or pools where a few sessile biota were found, or contained boulders or pieces of detached coral where small encrusting sponges occurred on the submerged undersides. 
Six intertidal stations were moderately species rich with between 10 and 20 sponge species present (Table 2). These were stations DA3/99/42 and DA3/99/51 (11 species), DA1/98/20 and DA3/99/ 54 (17 species), DA1/98/11 (19 species) and DA1/ 98/10 (20 species). These stations comprised partly submerged boulders, or deep pools or channels with attachment surfaces for sessile biota.

The remaining four intertidal stations, DA1/98/ $28,23,31$ and 17, were species rich with $22,26,27$ and 29 species respectively (Table 2). All these stations were in the northeast of the archipelago and were either in large bays with good water movement or on the edges of channels such as Searipple and Flying Foam Passages.

Only three intertidal stations were sampled for sponges during the workshop and two of these stations had low species diversity, i.e. < five species present. The third station (DA4/00/18) was in Flying Foam Passage and had moderate species diversity i.e. 15 species present (Appendices 6 and 9).

\section{Subtidal stations $<10 \mathrm{~m}$}

Thirty stations, 12 in the first (DA1/98) and 18 in the second (DA3/99) diving expeditions, occurred at depths of $<10 \mathrm{~m}$. Nineteen of these stations had 10 or fewer species of sponges present (Table 3 ). Stations DA1/98/09 and 16 had two species present, DA3/99/58 and 63 (4 species), DA1/98/24 (5 species), DA3/99/37 and 44 (6 species), DA1/ $98 / 19,22,35$ and DA3/99/36 (7 species), DA3/99/ 49,60 and 68 (8 species), DA3/99/41 and 47 (9 species) and DA1/98/29, DA3/99/46 and DA3/ $99 / 57$ (10 species).

Habitats at these stations were either algal dominated with sand cover (two stations), or consisted largely of coral rubble (two stations). Some stations were either low relief reef (four stations) or consisted of angular igneous boulders (one station), where small encrusting sponges could attach. Ten stations were dominated by hard corals where few attachment sites were available for other sessile invertebrates, or the sponges were cryptic. Multi-layered coral habitats such as Acropora thickets required destructive sampling to reach the basal layers where sponges might occur. This type of sampling was not attempted so an underestimation of sponge presence may have occurred at these sites.

Of the remaining 11 shallow water habitats sampled, 10 had moderate species richness with between 11 and 17 species present (Table 3). These were stations DA1/98/06 and DA3/99/61 (11 species), DA1/98/08 (12 species), DA1/98/ 03 and 12 , and DA3/99/64 (13 species), DA3/ $99 / 40$ and 53 (14 species) and DA1/98/01 and DA3/99/70 (17 species). These habitats consisted either of low relief reef or pavement areas with algal or hard coral prevalent (4 stations), or hard coral and dissected reef (4 stations). Two stations were dominated by either soft corals or gorgonians.

The shallow subtidal station DA1/98/33 in Flying Foam Passage was richest in terms of sponge diversity ( 38 species). This was a pavement habitat dominated by sponges, soft corals and gorgonians. Station DA1/98/33 was the shallowest site examined in the archipelago to have the type of habitat referred to as "sponge garden".

Of the five shallow subtidal stations sampled for sponges on the workshop expedition (DA4/00/01, $04,06,08$ and 23) all had low species diversity, i.e. $<10$ species per station. Twelve stations were $<10$ metres deep on the dredging expedition and six of these (DA2/99/01, 18, 19, 72, 91 and 95) had <10 sponge species present while a further three dredge hauls (DA2/99/15, 66 and 96) did not collect any sponges. These stations consisted principally of soft sediments or were dominated by algae. The remaining three shallow dredge stations (DA2/99/ 62, 68 and 70) had moderate species richness and dredge hauls were dominated by either sponges or corals, indicating that some hard substrata were available for attachment by sessile biota.

\section{Subtidal stations $>10 \mathrm{~m}$}

In the diving expeditions, only one subtidal station $>10 \mathrm{~m}$ depth did not contain sponges. This was station DA3/99/69, the only non-natural habitat sampled during the surveys and consisting of blocks of igneous rock over a gas pipe-line. Station DA1/98/30 had only one sponge species present. This was an homogenous substratum of soft sediments and shell grit with little habitat diversity. All macro-biota was sparse at this site.

Apart from the above two stations, species numbers in the deeper habitats tended to be higher on average than the intertidal and shallow subtidal habitats. Only three stations $>10 \mathrm{~m}$ depth had $<10$ sponge species. The remaining 13 stations had between 12 and 43 species present (Table 4 ).

The three stations with $<10$ species were stations DA3/99/39 and 43 (6 species) and 50 (7 species). These stations either consisted of angular blocks of igneous rock, pavement with occasional boulders and a few small or encrusting corals, soft corals and sponges, or hard corals on a dissected limestone reef (Table 4).

Six subtidal stations had between 12 and 18 sponge species. These were: station DA1/98/13 (12 species), DA3/99/52 (15 species), DA1/98/18 and DA3/99/67 (17 species) and DA1/98/21 and 26 (18 species). These were either dissected coral reef or pavement habitats and a single station (DA1/98/ 26) was a deep igneous outcrop (Table 4).

The remaining six stations had $>20$ species. Stations DA3/99/55 (22 species), DA1/98/15 (23 
species), DA1/98/27 (24 species) and DA3/99/56 (30 species) were pavement areas. Stations DA1/ 98/32 (24 species) and DA1/98/04 (29 species) were low relief coral reefs. Station DA3/99/65 had the highest species richness with 43 species and the type of habitat referred to as "sponge garden".

Nine subtidal stations $>10 \mathrm{~m}$ depth were sampled for sponges during the workshop expedition (DA4/00). Three of these had low species numbers (DA4/00/10, 12 and 22) and the remaining six (DA4/00/09, 14, 15, 16, 17 and 27) had moderate species richness (11-20 species). Fifty-four stations on the dredging expedition (DA2/99) were between $10-30 \mathrm{~m}$ in depth and the majority of these had low species diversity i.e. 28 stations had $<10$ species and 15 stations did not have sponges in the dredge hauls (Table 5). Stations where sponges were absent were often sand, mud, gravel or a combination of these substratum types. Those with few sponges were frequently dominated by either algae or hydroids. Of the remaining 11 stations, 10 had moderate species numbers (11-20 species) and one was species rich with more than 20 (Table 5). Dredge hauls from these stations were often dominated by sponges.

The dredging expedition (DA2/99) also sampled stations that were $>30 \mathrm{~m}$ depth. At these depths, only one station (DA2/99/08) had moderate species diversity whilst 18 had $<10$ species and nine dredge haul stations had no sponges. Those stations without sponges were usually dominated by algae and hydroids and sometimes gorgonians; those with some sponges had rocks and a diversity of sessile biota in the hauls.

\section{Station Summary}

Most of the intertidal stations had between 6 and 20 species present (62\%, Table 6), with four (19\%) having between $21-30$ species. In the shallow subtidal habitats ( $<10 \mathrm{~m}$ depth), the majority of the stations (50\%) had low species numbers, between 6-10 species. Thirty-three percent had between 11 and 20 species and $13 \%$ had fewer than five species present. One shallow subtidal station had over 30 species present. Of the deep subtidal stations $(>10$ $m$ depth), most (66\%) had between 11 and 30 sponge species present and only three had between $6-10$ species. One station at these depths had $>30$ species.

The results of the workshop expedition showed similar results (Table 7). Intertidal stations had $<10$ species except for one which had 15. The shallow subtidal habitats all had $<10$ species present, whereas the deeper subtidal stations consistently had more species present with $66 \%$ of these having between 11-20 species.

The majority of the dredge stations over all depths had $<10$ species present (52 out of 94 stations sampled for sponges) and another large proportion (27 stations) did not have any sponges. Fifteen of the dredge stations had between 11 and 30 species (Table 5 ).

\section{DISCUSSION}

In the intertidal habitats, sponges were rarest in areas where there was a pronounced oyster/ barnacle zone and little other hard substratum for attachment, or where moisture retention in pools or beneath substrata was limited to the extent that sponges would desiccate at low tide. Encrusting sponges were found under small rocks, boulders and coral that were unlikely to be disturbed by normal sea conditions. Highest diversity of large sponges was in areas with some basal pavement or coral cover that could act as attachment sites and that tended to remain partly submerged. Stations with channels, pools or lagoons had higher species numbers than those without these features. The majority of the intertidal stations had moderate species richness of between 6 and 20 species. Four had high species richness i.e. $>21$ species. These species rich stations were on the edges of channels with strong tidal movement, e.g. Flying Foam Passage and Searipple Passage, and one was in a large NNE facing bay on a silty intertidal flat.

Most of the subtidal stations $<10 \mathrm{~m}$ depth had low species richness (6-10 species), whereas one third of them had moderate species richness (11-20 species). One station in Flying Foam Passage and a second near Mermaid Strait had high sponge diversity and were examples of "sponge garden" habitat. These areas are either low relief or pavement habitats, often with a sediment layer and always with a high diversity of sponges and sessile coelenterates such as gorgonians and soft corals. These environments had strong tidal currents and were difficult to survey. These areas are presently under-sampled for species richness because of the difficulties associated with diver safety.

In the shallow subtidal habitats the presence of coarse sand precluded high sponge diversity. Where the dominant coral type did not allow for attachment sites, sponges were also lower in diversity, e.g. stations with large Porites bommies. A few stations had high coral cover with a multilayered (tiered) structure. Sponges may have been present in the basal layers but no destructive sampling was attempted to determine if they were present. Stations dominated by coral rubble offered few attachment sites for sponges. The shallow subtidal locations with reasonable sponge diversity were those with attachment sites such as plate or branching corals.

In the deeper subtidal habitats $>10 \mathrm{~m}$ depth, although coral cover remained high, many of the sponges were large and occurred in full light. Numbers of species were consistently higher at 
these stations than at the shallower subtidal stations and the intertidal areas. Of the 27 subtidal stations that were $>10 \mathrm{~m}$ deep, 18 had high species richness with 11-30 species present. These habitats were either in exposed localities on the NE side of Legendre Island, off islands in the region of Mermaid Strait, and one workshop station in Mermaid Sound, an area not sampled in the diving expeditions. The majority of these stations were either of low relief coral reef or pavement areas of the sponge garden type, frequently with strong current flow. Station DA3/99/65 near Mermaid Strait, with the highest species richness of all stations, was also of this habitat type. Mermaid Strait is the type locality for four species of sponges described by Lendenfeld (1907). Only two of these were recollected during this study.

Deep subtidal stations that were species rich on the dredging expedition were in the same localities as the species rich stations from the diving and workshop expeditions, such as Flying Foam Passage and habitats around Mermaid Strait.

Although dredging stations are not directly comparable with stations where sponges were collected by SCUBA or reef-walks because of major differences in sampling times (10 minute dredge tow compared to one to two hours SCUBA or reef walk), it is interesting that highest sponge diversity identified by this method was found in the same areas as on the diving and workshop expeditions.

Dredging stations with either no or few sponges were on the edge of the archipelago and at locations where the substrata were often fine silty sand and/ or muddy sand with only occasional rocky patches for attachment. Dive sites of this bottom type, e.g. DA1/98/30, were also depauperate in sponges. Within the archipelago, small scale heterogeneity in terms of sponge distributions was clearly indicated by the results of the dredging expedition. Some stations with either few or no sponges were adjacent to others with moderate to high species richness.

Some dredging stations were located in Nickol Bay which was an area not sampled in the diving and workshop expeditions. The stations closest to the Burrup Peninsula did not have any sponges but further into the bay low numbers were found and station DA2/99/13, on the outer edge of the bay, was rich in sponges. Nickol Bay is the type locality for Axos cliftoni.

The two stations located where anthropogenic influences were detected were depauperate in terms of sponges. Stations DA3/99/63 and 64 were near the iron ore loading jetties and contained a fragment of sponge and no sponge, respectively, in the dredge hauls. No sponges were reported from the "artificial reef" protecting the subtidal pipe-line running through the archipelago, which was installed in 1983. This may in part be due to a lack of nearby adult sessile benthos to supply recruits, and/or the igneous nature of the substratum which frequently has fewer sessile benthos than limestone. The pipe-line may also have been treated with an anti-fouling substance to prevent benthic recruitment but this has not been clarified.

In conclusion, the Dampier Archipelago marine environment provides a diversity of habitats for colonisation by sessile benthos. Sponges were recorded in large numbers from channels and straits and off islands in areas where there was good current flow. Throughout the archipelago, a fine scale mosaic of species rich and species poor areas is apparent.

\section{ACKNOWLEDGEMENTS}

I thank J. Ralston and the crew of the Kimberley Quest for their help on deck during the first diving expedition and B. Kirkwood and the crews of Top Gun II for their assistance during the second diving trip and workshop expedition. M. Hewitt, S. Morrison, J. Griffith, S. Slack-Smith, C. Bryce, B. Hutchins, P. Morrison, M. Vanderklift, P. Berry and $R$. Peart assisted on the field trips when too many species were collected. Many thanks are extended to M. Hewitt and S. Slack-Smith for collecting sponges on the dredging expedition. M. Salotti assisted with preparations for all of the expeditions, databased the resulting sponge collections and assisted with the appendices. The fieldwork was funded by Woodside Energy Ltd.

\section{REFERENCES}

Fromont, J. (1998). Revision of the marine sponge genus Caulospongia Saville-Kent, 1871 (Demospongiae: Hadromerida). Part 1. Morphological and skeletal characters. Records of the Western Australian Museum 19: 65-89.

Fromont, J. (2003). Porifera (sponges) in the Dampier Archipelago: taxonomic affinities and biogeography. In Wells, F.E., Walker, D.I. and Jones, D.S. (eds), Proceedings of the Eleventh International Marine Biological Workshop: The Marine Flora and Fauna of Dampier, Western Australia 2: 405-417. Western Australian Museum, Perth.

Fromont, J., Vanderklift, M., and Kendrick, G. (in prep.) Marine sponges of the Dampier Archipelago, Western Australia: patterns of species distributions, richness and biodiversity.

Hooper, J.N.A. (1986). Revision of the marine sponge genus Axos Gray (Demospongiae: Axinellida) from north-west Australia. The Beagle, Occasional papers of the Northern Territory Museum of Arts and Sciences 3: 167-189.

Hooper, J.N.A. (1991). Revision of the family Raspailiidae (Porifera: Demospongiae), with description of Australian species. Invertebrate Taxonomy 5: 1179-1415. 
Hooper, J.N.A. (1993). Axinellida (Porifera: Demospongiae) from the New Caledonia Lagoon. Invertebrate Taxonomy 7: 1395-1472.

Hooper, J.N.A. (1996). Revision of Microcionidae (Porifera: Demospongiae), with description of Australian species. Memoirs of the Queensland Museum 40: 1-626.

Jones, D. S. (2004). The Burrup Peninsula and Dampier Archipelago, Western Australia: an introduction to the history of its discovery and study, marine habitats and their flora and fauna. In Jones, D. S. (ed.), Report on the Results of the Western Australia Museum/Woodside Energy Ltd. Partnership to explore the Marine Biodiversity of the Dampier Archipelago, Western Australia, 19982002. Records of the Western Australian Museum, Supplement 66: 27-49.

Lendenfeld, R. von (1907). Die Tetraxonia. In Chun, C. (ed), Wissenschaftliche Ergebnisse der Deutschen TiefseeExpedition auf dem Dampfer "Valdivia" 1898-1899 11: 59-374.

Table 1 Published records of sponge species from the Dampier Archipelago.

\begin{tabular}{llll}
\hline Species & Location & Depth (m) & Reference \\
\hline Cinachyra isis & Mermaid Strait (TL) & Lendenfeld, 1907 \\
Stelletta nereis & Mermaid Strait (TL) & Lendenfeld, 1907 \\
Corticium simplex & Mermaid Strait (TL) & Lendenfeld, 1907 \\
Isops toxoteuches & Mermaid Strait (TL) & Lendenfeld, 1907 \\
Axos cliftoni & Nickol Bay (TL) & & Hooper, 1986 \\
Axos flabelliformis & NW of Dampier Arch. & 26 & Hooper, 1986 \\
Trikentrion flabelliforme & NW of Dampier Arch. & 35 & Hooper, 1991 \\
Echinodictyum cancellatum & NW of Dampier Arch. & 108 & Hooper, 1991 \\
Echinodictyum conulosum & W end Lewis Island & 8 & Hooper, 1991 \\
Echinodictyum mesenterinum & NW and N of Dampier Arch. & $30-53$ & Hooper, 1991 \\
Myrmekioderma granulata & Enderby Island & 14 & Hooper, 1993 \\
Echinochalina (Echinochalina) intermedia & NW of Dampier Arch. & 29 & Hooper, 1996 \\
Caulospongia amplexa & NW Rosemary Island (TL) & $70-71$ & Fromont, 1998 \\
Caulospongia plicata & NNE Cape Lambert & $37-39$ & Fromont, 1998 \\
\hline
\end{tabular}

$\mathrm{TL}=$ Type locality. 
Table 2 Total number of sponge species found at each of the intertidal stations and descriptions of habitats on the diving expeditions DA1/98 and DA3/99. Latitudes and longitudes of each station are given in Appendix 2 and a map of the localities in Appendix 3.

\begin{tabular}{lll}
\hline $\begin{array}{l}\text { Station } \\
\text { number }\end{array}$ & $\begin{array}{l}\text { Total } \\
\text { number } \\
\text { species }\end{array}$ & Station Description \\
& &
\end{tabular}

DA1/98/02 8 Bay - E side Dolphin I. Habitat: Mangrove. Oysters at edge of mudflat with small rocks,

DA1/98/05 2 Reef flat E tip Legendre I. Habitat: Oyster dominated walls, pavement with zoanthids, high silt, some pools and flowing water, Goniastrea bommies abundant on reef edge, rare sponges in pools.

DA1/98/07 3 W side, towards S end Gidley I. Habitat: Large igneous boulders with oysters and barnacles, shallow rock pools with algal mats at edges, shallow limestone platform with rare sponges.

DA1/98/10 $20 \quad N$ facing site - W side Angel I. Habitat: Edge of channel, mangrove and oyster on shoreline, beach rock with silt coating at edge of channel. In channel numerous small coral colonies, algae, sponges on and between pavement.

DA1/98/11 19 W side Dolphin I., towards S end. Habitat: Mangrove and oyster zone with sharp igneous rocks at headlands, silty flat between with some pavement, many hard corals, soft corals, ascidians (not noted at other sites) and sponges different from Stn.10.

DA1/98/14 9 S end Unnamed I. Habitat: (2 sites) 1. Igneous boulders with oyster and barnacie fringe, algae on submerged rock with sand cover. 2 . Channel between two islands with deep sand gutters, small coral colonies and micro-atolls, low sponge diversity.

DA1 $/ 98 / 17 \quad 29$

$\mathrm{N}$ end Wilcox I. Habitat: Sandy point and channel, silty sand, many hard corals, soft corals, gorgonians, sponge diversity high. Bioeroding sponges in silty mud at end of point.

SE side Collier Rocks. Habitat: Low relief reef edge with shallow lagoon inside, abundant Fungia, Acropora to shoreward, silty, sponges reasonably diverse.

NE facing bay E side Dolphin I. Habitat: Silty sand with isolated coral colonies, filamentous algae, very silty, sponges diverse.

SE end Keast I. Habitat: Sand mound with intertidal bank with coarse sandy sediment and coral rubble, large pieces of plate Acropora, some sponges beneath.

NW side Dolphin I. towards $N$ end. Habitat: Thin mangrove fringe, sharp boulders with oysters and barnacles, silty to seaward, encrusting sponges under boulders at water line, most diverse in recess in bay where more water movement and less mud.

E end Searipple Passage. Habitat: Abundant hard coral, diverse sponges attached to coral plates, many bioeroding sponges in coral, sediment more silty towards mangrove.

DA3/99/38 $10 \quad$ N side Malus I. Habitat: Coarse sand beach grading into limestone boulders towards shoreline. Low relief. Sponges and corals rare.

Georgeff Reef. Habitat: Small limestone boulders towards waterline, numerous Acropora and faviid colonies. Holothurians and sponges present.

DA3/99/45 $8 \quad$ S side Rosemary I. east of Tish Point. Habitat: Small igneous rocks to low relief algal dominated rock, isolated coral colonies on outer edge grading into sand, some soft coral and sponges.

DA3/99/48 $6 \quad$ N side Goodwyn I. Habitat: Low relief. Some gutters with flowing water or pools with algae. Corals on outer edges mainly massive faviids and Turbinaria, few Acropora, low diversity. Low diversity of sponges, rare soft corals, one gorgonian.

N Enderby I. Habitat: Silty sand flat with fine sediment and algae and deep pools towards shoreline with coral around edges.

DA3/99/54 $17 \quad$ E side Enderby I., southern end of large bay. Habitat: Silty intertidal flat with sparse algae, some sponges, numerous holothurians.

DA3/99/59 4 N side West Lewis I. Habitat: Mangrove fringed bay with small igneous rocks, some larger boulders with oyster. Bay with more sandy towards entrance. Low incidence of sponges and corals where bay is slow draining.

DA3/99/62 2 S side East Lewis I. Habitat: Bays fringed by thick band of mangrove. Intertidal flat with oyster covered igneous boulders, some algae, coral and sponges rare.

DA3/99/66 7 S coast Enderby I. Habitat: Tidal creek with rocks and muddy sand. Some corals and sponges, mainly Cyphastrea, Goniastrea, Galaxea, Tridacna maxima present, most common sponge Haliclona cymaeformis. 
Table 3 Total number of sponge species found at each of the subtidal stations ( $<10$ metres) and descriptions of habitats on the diving expeditions DA1/98 and DA3/99. Latitudes and longitudes of each station are given in Appendix 2 and a map of the localities in Appendix 3.

\begin{tabular}{|c|c|c|}
\hline $\begin{array}{l}\text { Station } \\
\text { number }\end{array}$ & $\begin{array}{l}\text { Total } \\
\text { number } \\
\text { species }\end{array}$ & Station Description \\
\hline $\mathrm{DAl} / 98 / 01$ & 17 & $\begin{array}{l}\text { NE end Dolphin I. Maximum depth: } 6.0 \mathrm{~m} \text {. Habitat: Shallow hard coral habitat, mainly small } \\
\text { colonies, low relief, silty sand between reef, sponges generally small and cryptic. }\end{array}$ \\
\hline DA1/98/03 & 13 & $\begin{array}{l}\text { W side Legendre I. Maximum depth: } 9.0 \mathrm{~m} \text {. Habitat: Abundant small hard coral colonies, high } \\
\text { cover, low relief, silty sand in deep gutters between bommies, sponges small, cryptic, some } \\
\text { species large in full light. }\end{array}$ \\
\hline DA1/98/06 & 11 & $\begin{array}{l}\text { NW end Haüy I. Maximum depth: } 3.0 \mathrm{~m} \text {. Habitat: Flat pavement, algal growth, small coral } \\
\text { colonies, low relief, silty sand cover, encrusting and erect sponges. }\end{array}$ \\
\hline DA1/98/08 & 12 & $\begin{array}{l}\text { W side Angel I. Maximum depth: } 7.0 \mathrm{~m} \text {. Habitat: Coral reef, many shallow gullies and } \\
\text { overhangs, small coral colonies, many plate corals mainly Acropora, sponges mainly under } \\
\text { overhangs and plates. }\end{array}$ \\
\hline DA1/98/09 & 2 & $\begin{array}{l}\text { NW facing bay W side Angel I. Maximum depth: } 4.6 \mathrm{~m} \text {. Habitat: Fragmented pavement, algae } \\
\text { and sand cover, no coral, sponges rare. }\end{array}$ \\
\hline DA1/98/12 & 13 & $\begin{array}{l}\text { Bay - W side Angel I. Maximum depth: } 5.8 \mathrm{~m} \text {. Habitat: Coral reef with Porites bommies and } \\
\text { many dead massive and Acropora colonies, attachment sites for corals and sponges, silt } \\
\text { covered. }\end{array}$ \\
\hline DA1/98/16 & 2 & $\begin{array}{l}\text { W side Hamersley Shoal. Maximum depth: } 3.3 \mathrm{~m} \text {. Habitat: Coral rubble, low relief, silt cover, } \\
\text { sponges rare. }\end{array}$ \\
\hline DA1/98/19 & 7 & $\begin{array}{l}\text { SE tip Haüy I. Maximum depth: } 2.7 \mathrm{~m} \text {. Habitat: Coral rubble, small live corals, thin silt layer, } \\
\text { sponges encrusting. }\end{array}$ \\
\hline DA1/98/22 & 7 & $\begin{array}{l}\text { NNW edge Delambre I. Maximum depth: } 5.4 \mathrm{~m} \text {. Habitat: Abundant plate and branching } \\
\text { Acropora, one area bleached? coral (living tips), sponges under or between plates. }\end{array}$ \\
\hline DA1/98/24 & 5 & $\begin{array}{l}\text { E side Dolphin I. Maximum depth: } 7.0 \mathrm{~m} \text {. Habitat: Hard corals and silt cover, sponges } \\
\text { encrusting. }\end{array}$ \\
\hline $\mathrm{DA} 1 / 98 / 29$ & 10 & $\begin{array}{l}\text { S side Legendre I. Maximum depth: } 4.4 \mathrm{~m} \text {. Habitat: High hard coral cover, large staghorns, } \\
\text { large vertical depth, sponges encrusting on live coral vertical plates. }\end{array}$ \\
\hline DA1/98/33 & 38 & $\begin{array}{l}\text { NNE tip Angel I. Maximum depth: } 8.2 \mathrm{~m} \text {. Habitat: reef pavement, coarse shelly grit and silt, } \\
\text { sponges abundant. }\end{array}$ \\
\hline $\mathrm{DA} 1 / 98 / 35$ & 7 & $\begin{array}{l}\text { SW facing side - Legendre I. Snorkel dive. Maximum depth: } 1.0 \mathrm{~m} \text {. Habitat: Small bommies } \\
\text { and micro-atolls, flattened dead tops on coarse sand. Sponges rare. }\end{array}$ \\
\hline $\mathrm{DA} 3 / 99 / 36$ & 7 & $\begin{array}{l}\text { N side Malus I. - eastern end. Maximum depth: } 9.8 \mathrm{~m} \text {. Habitat: Low relief, slight slope, good } \\
\text { coral diversity, common corals Acropora, Turbinaria, Porites, some sponges and soft corals. }\end{array}$ \\
\hline $\mathrm{DA} 3 / 99 / 37$ & 6 & $\begin{array}{l}\text { W side Malus I. Maximum depth: } 3.8 \mathrm{~m} \text {. Habitat: Sand and algal covered broken pavement, } \\
\text { rubble. Lots of Turbinaria. }\end{array}$ \\
\hline $\mathrm{DA} 3 / 99 / 40$ & 14 & $\begin{array}{l}\text { W of Brigadier I. Maximum depth: } 9.4 \mathrm{~m} \text {. Habitat: Low relief dropping to sand, clefts, gulleys. } \\
\text { Dominated by soft corals, some hard corals Acropora, Porites, Galaxea, faviids, low diversity of } \\
\text { sponges. }\end{array}$ \\
\hline $\mathrm{DA} 3 / 99 / 41$ & 9 & $\begin{array}{l}\text { S of Georgeff Reef. Maximum depth: } 4.9 \mathrm{~m} \text {. Habitat: Coarse coralline sand, low relief, } \\
\text { occasional gorgonians, sea whips. }\end{array}$ \\
\hline $\mathrm{DA} 3 / 99 / 44$ & 6 & $\begin{array}{l}\text { S of Gordon Point, Rosemary I. Maximum depth: } 6.0 \mathrm{~m} \text {. Habitat: Large Porites bommies, coarse } \\
\text { sand, some limestone reef between with siltier sand and some soft corals, hydroids, ascidians } \\
\text { and sponges. }\end{array}$ \\
\hline $\mathrm{DA} 3 / 99 / 46$ & 10 & NW side Kendrew I. Maximum depth: $7.4 \mathrm{~m}$. Habitat: Coral on dissected limestone reef. \\
\hline $\mathrm{DA} 3 / 99 / 47$ & 9 & $\begin{array}{l}\text { SE side Kendrew I. Maximum depth: } 4.8 \mathrm{~m} \text {. Habitat: Low relief pavement, small coral colonies } \\
\text { mainly Turbinaria, some Acropora, small favids, and algae. }\end{array}$ \\
\hline $\mathrm{DA} 3 / 99 / 49$ & 8 & $\begin{array}{l}\text { S side Goodwyn I. Maximum depth: } 5.0 \mathrm{~m} \text {. Habitat: Large Porites bommies on sand, robust } \\
\text { corals, some sponges. }\end{array}$ \\
\hline $\mathrm{DA} 3 / 99 / 53$ & 14 & $\begin{array}{l}\text { NE end Enderby I. Maximum depth: } 5.3 \mathrm{~m} \text {. Habitat: Silty sand, high diversity sponges, also } \\
\text { soft corals and gorgonians, diverse Acropora. }\end{array}$ \\
\hline $\mathrm{DA} 3 / 99 / 57$ & 10 & $\begin{array}{l}\text { NE of North-west reef. Maximum depth: } 9.4 \mathrm{~m} \text {. Habitat: Igneous angular boulders covered } \\
\text { with fine sediment, few encrusting sponges and small soft corals, few hard corals. }\end{array}$ \\
\hline $\mathrm{DA} 3 / 99 / 58$ & 4 & $\begin{array}{l}\text { Large bay } \mathrm{E} \text { end of } \mathrm{N} \text { coast, Enderby I. Maximum depth: } 3.6 \mathrm{~m} \text {. Habitat: Coral over coarse } \\
\text { sand, rubble, high diversity of coral, many fragile colonies, Acropora common, sponges } \\
\text { uncommon. }\end{array}$ \\
\hline $\mathrm{DA} 3 / 99 / 60$ & 8 & $\begin{array}{l}\text { N side West Lewis I. Maximum depth: } 4.1 \mathrm{~m} \text {. Habitat: Extensive coral reef particularly Pavona } \\
\text { decussata. }\end{array}$ \\
\hline $\mathrm{DA} 3 / 99 / 61$ & 11 & $\begin{array}{l}\text { E coast West Lewis I. Maximum depth: } 5.0 \mathrm{~m} \text {. Habitat: Low relief, fine sand some rubble, } \\
\text { abundant algae, some large Pavona but mainly small coral colonies, some sponges, all beneath } \\
\text { algae. }\end{array}$ \\
\hline
\end{tabular}


Table 3 (cont.)

\begin{tabular}{lll}
\hline $\begin{array}{l}\text { Station } \\
\text { number }\end{array}$ & $\begin{array}{l}\text { Total } \\
\text { number } \\
\text { species }\end{array}$ & Station Description \\
&
\end{tabular}

DA3/99/63 4 SW end East Lewis I. Maximum depth: $4.4 \mathrm{~m}$. Habitat: Diverse coral, some encrusting, abundant Echinopora, high Porites columns with silty sediment cover, substrate grades into sandy silt.

DA3/99/68 8

West Lewis I., off S coast. Maximum depth: $5.3 \mathrm{~m}$. Habitat: Low relief, fine sand, patchy small bommies and clusters of coral, mostly Pavona, Porites and Acropora.

DA3/99/70 $\quad$ 'with some sponges and ascidians, algae most dominant.

DA3/99/70 17 NE Nelson rocks. Maximum depth: $5.0 \mathrm{~m}$. Habitat: Macroalgae on pavement, some coral and sponge. 
Table 4 Total number of sponge species found at each of the subtidal stations ( $>10$ metres) and descriptions of habitats on the diving expeditions DA1/98 and DA3/99. Latitudes and longitudes of each station are given in Appendix 2 and a map of the localities in Appendix 3.

\begin{tabular}{|c|c|c|}
\hline $\begin{array}{l}\text { Station } \\
\text { number }\end{array}$ & $\begin{array}{l}\text { Total } \\
\text { number } \\
\text { species }\end{array}$ & Station Description \\
\hline DA1/98/04 & 29 & $\begin{array}{l}\mathrm{N} \text { side Legendre I. Maximum depth: } 11.2 \mathrm{~m} \text {. Habitat: Abundant small hard coral colonies, } \\
\text { high \% cover, low relief, silty sand with few gutters between bommies, sponges high diversity } \\
\text { and cover. }\end{array}$ \\
\hline DA1/98/13 & 12 & $\begin{array}{l}\text { W side Hamersley Shoal. Maximum depth: } 15.3 \mathrm{~m} \text {. Habitat: Coral reef, shallow sand gutters at } \\
\text { right angles to reef crest, low relief with silt cover, sponges sparse. }\end{array}$ \\
\hline DA1/98/15 & 23 & $\begin{array}{l}\text { N side Legendre I. towards NW end. Maximum depth: } 16.4 \mathrm{~m} \text {. Habitat: Pavement with some } \\
\text { silt, soft corals dominant, some Porites bommies, many large sponges, diverse. }\end{array}$ \\
\hline DA1/98/18 & 17 & $\begin{array}{l}\text { N side Haüy I. towards NE end. Maximum depth: } 12.1 \mathrm{~m} \text {. Habitat: Massive Porites bommies } \\
\text { on sand, sponges in full light or under plates. }\end{array}$ \\
\hline $\mathrm{DA} 1 / 98 / 21$ & 18 & $\begin{array}{l}\mathrm{N} \text { end Delambre I. Maximum depth: } 13.9 \mathrm{~m} \text {. Habitat: Coral reef with abundant plates, } \\
\text { branching and massive corals, narrow gutters between, sponges large in full light or } \\
\text { encrusting sides of coral, also encrusting ascidians. }\end{array}$ \\
\hline $\mathrm{DA} 1 / 98 / 26$ & 18 & $\begin{array}{l}\text { Madeleine Shoals. Maximum depth: } 21.9 \mathrm{~m} \text {. Habitat: Deep outcrop, mainly encrusting hard } \\
\text { corals, faviids and plates, many small Dendronepthyea sponges either large mounds or cups } \\
\text { and extensive encrustations. }\end{array}$ \\
\hline DA1/98/27 & 24 & $\begin{array}{l}\mathrm{N} \text { side Legendre I. Maximum depth: } 16.0 \mathrm{~m} \text {. Habitat: Flat limestone pavement with silt, } \\
\text { gorgonians and sponges, some outcrops as flat rocks, low relief. }\end{array}$ \\
\hline DA1/98/30 & 1 & $\begin{array}{l}\text { NE end Burrup Peninsula. Maximum depth: } 11.1 \mathrm{~m} \text {. Habitat: Shell grit and silt substratum. } \\
\text { One species of sponge, Dendronepthyea, solitary ascidian, sparse biota. }\end{array}$ \\
\hline DA1/98/32 & 24 & $\begin{array}{l}\mathrm{N} \text { side Legendre I. Maximum depth: } 13.6 \mathrm{~m} \text {. Habitat: Abundant hard coral plates, massive } \\
\text { and branching colonies on reef slope, large gutters with sand, some high coral outcrops off } \\
\text { reef edge with sponges. }\end{array}$ \\
\hline DA3/99/39 & 6 & $\begin{array}{l}\text { NNE of Brigadier I. Maximum depth: } 15.0-17.0 \mathrm{~m} \text {. Habitat: Igneous spur, angular blocks, } \\
\text { spreading soft corals, sparse encrusting corals and sponges. }\end{array}$ \\
\hline $\mathrm{DA} 3 / 99 / 43$ & 6 & $\begin{array}{l}\text { Sailfish Reef. Maximum depth: } 12.2 \mathrm{~m} \text {. Habitat: Flat pavement with occasional boulders, corals } \\
\text { encrusting or very small, some soft corals, few sponges. }\end{array}$ \\
\hline DA3/99/50 & 7 & $\begin{array}{l}\text { SE Bare Rock. Maximum depth: } 16.4 \mathrm{~m} \text {. Habitat: Coral on dissected limestone reef, small } \\
\text { Porites bommies, plate corals and many Acropora. }\end{array}$ \\
\hline DA3/99/52 & 15 & $\begin{array}{l}\text { NW of Roly Rock. Maximum depth: } 16.1 \mathrm{~m} \text {. Habitat: Flat pavement with large soft corals and } \\
\text { gorgonians. }\end{array}$ \\
\hline $\mathrm{DA} 3 / 99 / 55$ & 22 & $\begin{array}{l}\text { Channel between Enderby and West Lewis Is. Maximum depth: } 17.6 \mathrm{~m} \text {. Habitat: Flat silt } \\
\text { covered pavement with high diversity of sponges, sea whips, and octocorals. Strong current } \\
\text { area, turbid. }\end{array}$ \\
\hline $\mathrm{DA} 3 / 99 / 56$ & 30 & $\begin{array}{l}\mathrm{N} \text { of NW point Eaglehawk Is. Maximum depth: } 11.5 \mathrm{~m} \text {. Habitat: Low relief pavement, sponge } \\
\text { garden, some hard corals, soft corals, gorgonians and sea whips. }\end{array}$ \\
\hline DA3/99/65 & 43 & SW Rocky Head. Maximum depth: $14.3 \mathrm{~m}$. Habitat: Sponge garden with sea whips. \\
\hline $\mathrm{DA} 3 / 99 / 67$ & 17 & $\begin{array}{l}\mathrm{N} \text { of Nelson Rocks. Maximum depth: } 17.0 \mathrm{~m} \text {. Habitat: Low relief pavement with fine silt cover, } \\
\text { small sponges and soft corals, encrusting corals and some plate coral, large Porites bommies in } \\
\text { shallower water. }\end{array}$ \\
\hline $\mathrm{DA} 3 / 99 / 69$ & 0 & $\begin{array}{l}\text { Igneous rock on pipeline. Maximum depth: } 16.1 \mathrm{~m} \text {. Few ascidians and encrusting sponges. } \\
\text { Few encrusting corals, some Turbinaria. }\end{array}$ \\
\hline
\end{tabular}


Table 5 Summary of species numbers at dredging stations (DA2/99) determined from counts of collected specimens and from notes on number of species recorded by collectors in the field (*absolute number of species not recorded in field).

\begin{tabular}{|c|c|c|c|c|c|c|c|c|}
\hline & & Specie & hness an & portion & tions wit & t number & pecies & \\
\hline & Depth & $\begin{array}{l}0 \\
\text { species }\end{array}$ & $\begin{array}{l}<5 \\
\text { species }\end{array}$ & $\begin{array}{l}6-10 \\
\text { species }\end{array}$ & $\begin{array}{l}11-20 \\
\text { species }\end{array}$ & $\begin{array}{l}21-30 \\
\text { species }\end{array}$ & $\begin{array}{l}>30 \\
\text { species }\end{array}$ & $\begin{array}{l}\text { Total no. } \\
\text { stations }\end{array}$ \\
\hline & $<10 \mathrm{~m}$ & 15 & 1 & 18 & 62 & & & \\
\hline & & 66 & 19 & $* 72$ & 68 & & & \\
\hline & & 96 & 91 & & $* 70$ & & & \\
\hline & & & 95 & & & & & \\
\hline & total no. stations & 3 & 4 & 2 & 3 & 0 & 0 & 12 \\
\hline & $\%$ & $25 \%$ & $33 \%$ & $17 \%$ & $25 \%$ & & & \\
\hline & $>10 \mathrm{~m}$ & 16 & 2 & 10 & 13 & 37 & & \\
\hline & & 17 & 21 & 32 & $* 39$ & & & \\
\hline & & 20 & 29 & 33 & 49 & & & \\
\hline & & 30 & 31 & 41 & 50 & & & \\
\hline & & 35 & 34 & 58 & 59 & & & \\
\hline & & 45 & 36 & & 60 & & & \\
\hline & & 46 & 38 & & $* 65$ & & & \\
\hline & & 47 & 40 & & $* 75$ & & & \\
\hline & & 61 & 42 & & $* 84$ & & & \\
\hline & & 64 & 43 & & $* 99$ & & & \\
\hline & & 71 & 44 & & & & & $\cdot$ \\
\hline$\stackrel{\Delta}{=}$ & & 76 & 48 & & & & & \\
\hline 范 & & 89 & 63 & & & & & \\
\hline 告 & & 93 & 67 & & & & & \\
\hline 동 & & 94 & 69 & & & & & \\
\hline 然 & & & 73 & & & & & \\
\hline क & & & 74 & & & & & \\
\hline ڤี & & & 77 & & & & & \\
\hline $\bar{E}$ & & & 78 & & & & & \\
\hline$\Xi$ & & & 83 & & & & & \\
\hline 5 & & & 85 & & & & & \\
\hline تِّتِ & & & 92 & & & & & \\
\hline & & & 98 & & & & & \\
\hline & total no. stations & 15 & 23 & 5 & 10 & 1 & 0 & 54 \\
\hline & $\%$ & $28 \%$ & $42 \%$ & $9 \%$ & $19 \%$ & $2 \%$ & & \\
\hline & $>30 \mathrm{~m}$ & 23 & 3 & 4 & 8 & & & \\
\hline & & 27 & 5 & 9 & & & & \\
\hline & & 28 & 6 & $* 82$ & & & & \\
\hline & & 52 & 7 & & & & & \\
\hline & & 54 & 12 & & & & & \\
\hline & & 57 & 22 & & & & & \\
\hline & & 81 & 24 & & & & & \\
\hline & & 87 & 25 & & & & & \\
\hline & & 88 & 26 & & & & & \\
\hline & & & 51 & & & & & \\
\hline & & & 53 & & & & & \\
\hline & & & 55 & & & & & \\
\hline & & & 56 & & & & & \\
\hline & & & 79 & & & & & \\
\hline & & & 90 & & & & & \\
\hline & total no. stations & 9 & 15 & 3 & 1 & 0 & 0 & 28 \\
\hline & $\%$ & $32 \%$ & $54 \%$ & $11 \%$ & $3 \%$ & & & \\
\hline
\end{tabular}


Table 6 Summary of species numbers found at stations from the two diving expeditions (DA1/98, DA3/99) categorised into intertidal, $<10$ metres depth and $>10$ metres depth.

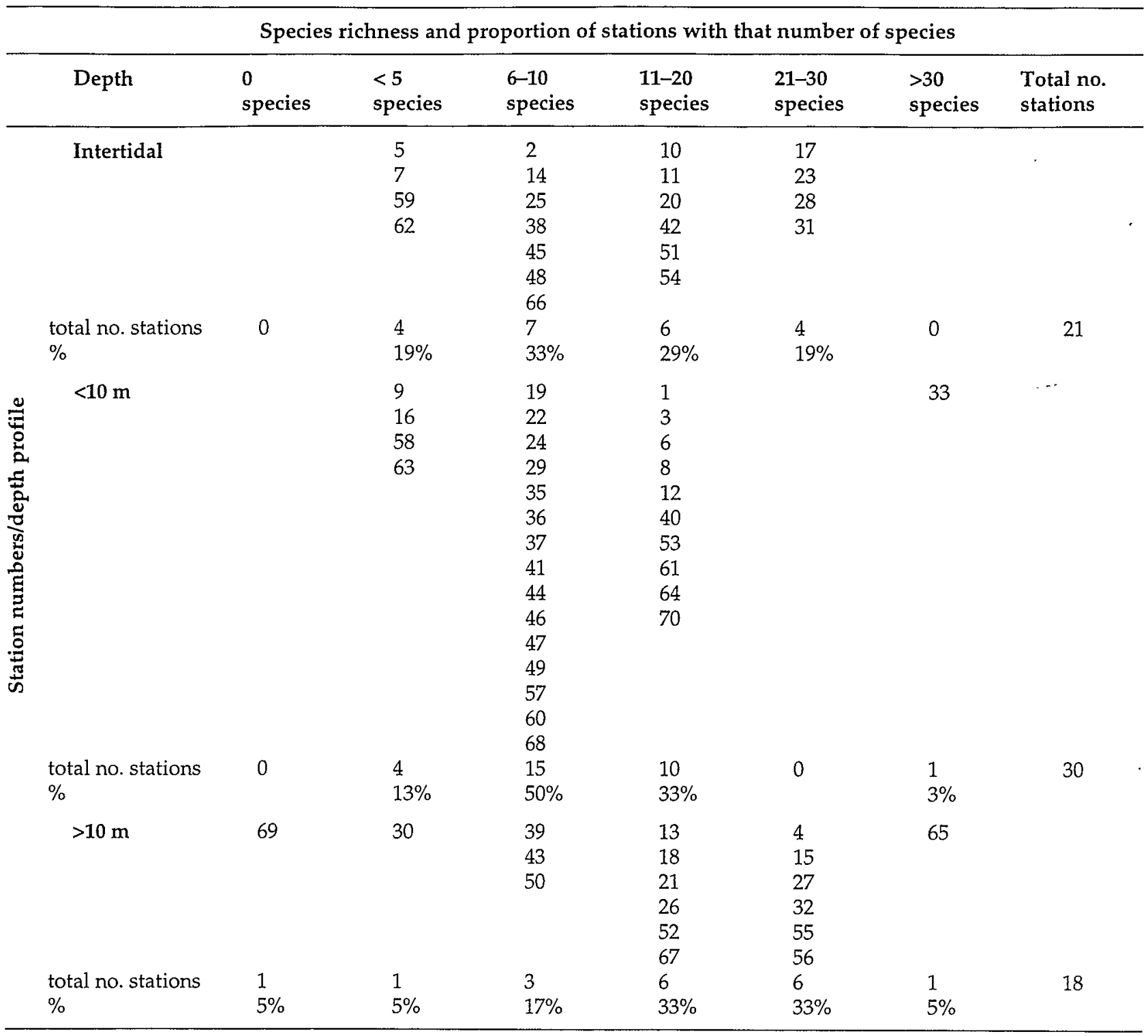


Table 7 Summary of species numbers at workshop stations (DA4/00) categorised into intertidal, $<10$ metres depth and $>10$ metres depth.

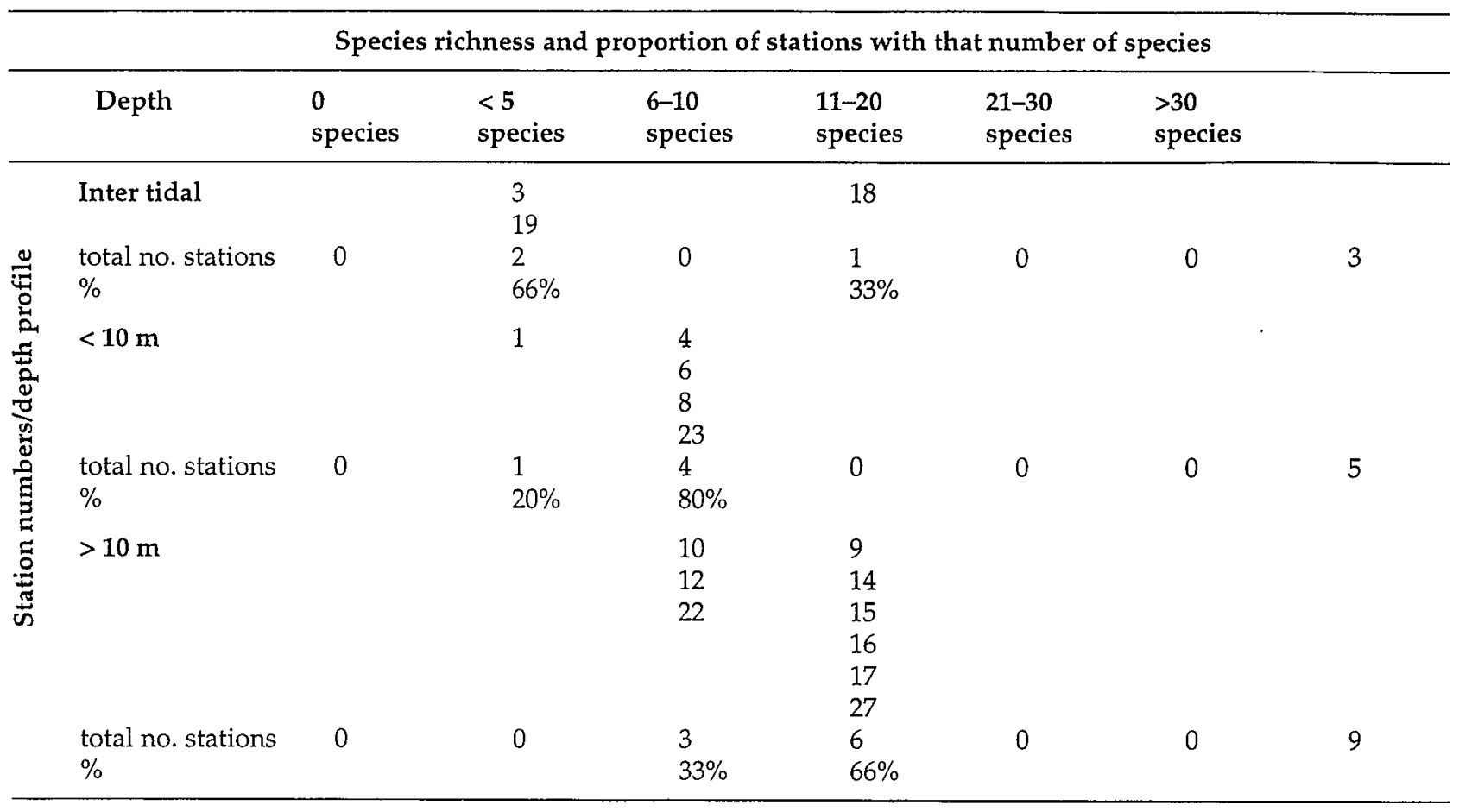


Appendix 1 Species collected on diving expeditions DA1/98 and DA3/99: $1=$ species present at station; ${ }^{*}=$ species collected on DA1/98 only; ${ }^{* *}=$ collected on DA3/99 only.

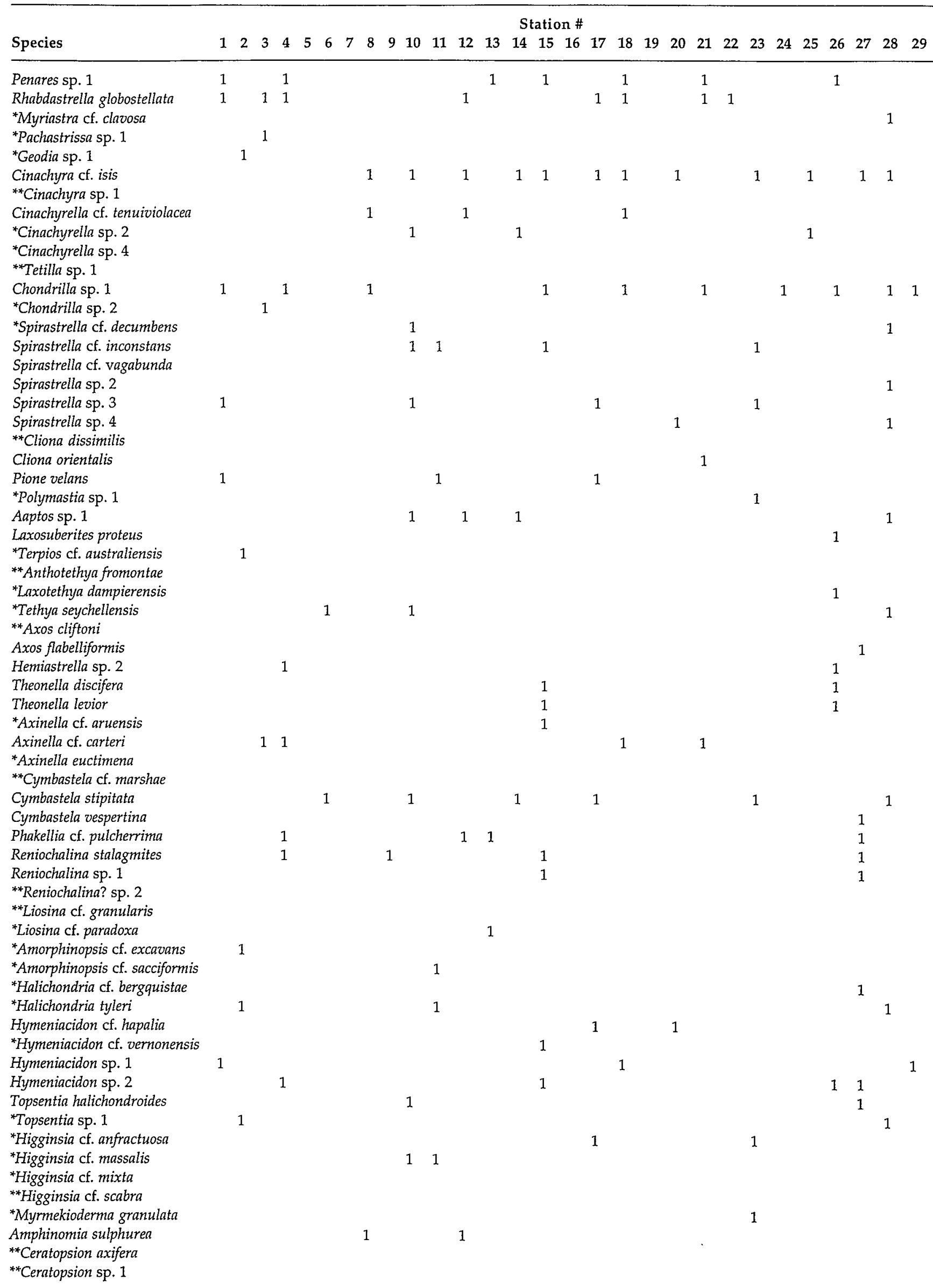


Station \#

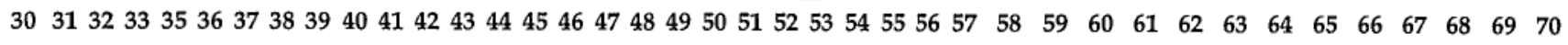

$\begin{array}{lllllllllllllllll}1 & 1 & 1 & & & 1 & 1 & 1 & 1 & 1 & 1 & 1 & 1 \\ 1 & 1 & & & 1 & 1 & 1 & 1 & 1 & 1 & 1\end{array}$

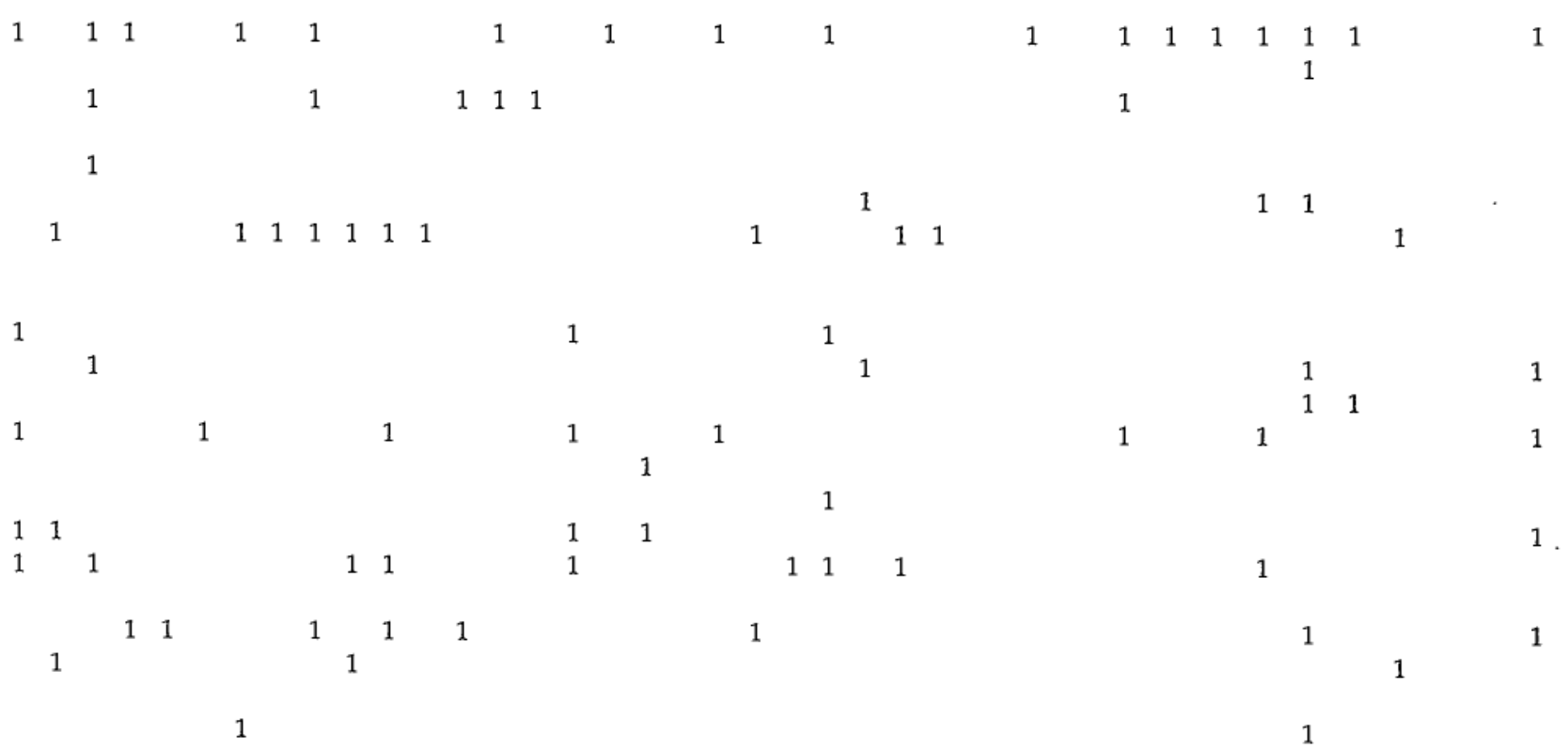

11

1

1

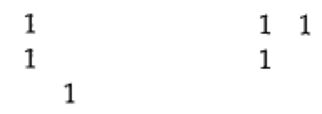

1

11

1
1

1

1

1

1

1

1

11

1

$\begin{array}{llll}1 & 1 & 1 & 1\end{array}$

11

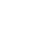
(n) 1. 1 
Station \#

** Echinodictyum cancellatum

${ }^{*}$ Echinodictyum clathrioides

Echinodictyum mesenterinum

* Ectyoplasia frondosa

*Ectyoplasia tabula

Ectyoplasia vannus

Raspailia (Raspailia) cf. phakellopsis

**Raspailia (Raspailia) vestigifera

Raspailia (Raspaxilla) wardi

*Thrinacophora cervicornis

*Thrinacophora sp. 1

Trikentrion flabelliforme

*Neofibularia? sp. 1

Biemna trirhaphis

*Biemna sp. 1

*Biemna sp. 2

Tedania sp. 1

*Hymedesmia sp. 1

*Coelocarteria singaporense

*Cornulum cf. strepsichela

*Phoriospongia sp. 1

**Phoriospongia sp. 2

Psammoclema sp. 1

*Tetrapocillon sp. 1

**Phorbas sp. 1

Desmapsamma sp. 1

* Iotrochota baculifera

*Iotrochota cf. faveolaria

*Iotrochota sp. 1

* Acarnus cf. tortilis

* Acarnus cf. wolfgangi

Clathria (Isociella) eccentrica

Clathria (Microciona) cf. lizardensis

**Clathria (Thalysias) abietina

**Clathria (Thalysias) lendenfeldi

*Clathria (Thalysias) major

Clathria (Thalysias) reinwardti

Clathria (Thalysias) vulpina

Clathria (Wilsonella) cf. claviformis

**Echinochalina (Echinochalina) cf. intermedia

Mycale cf. phyllophila

Mycale sp. 1

${ }^{*}$ Mycale sp. 2

Mycale sp. 3

*Mycale sp. 4

*Mycale sp. 5

**Mycale? sp. 6

Haliclona amboinensis

Haliclona cymaeformis

Haliclona sp. 4

*Haliclona sp. 5

*Haliclona sp. 6

*Haliclona sp. 7

Haliclona sp. 8

Haliclona sp. 9

**Haliclona sp. 10

**Haliclona sp. 11

**Haliclona sp. 12

**Haliclona sp. 13

*Haliclona sp. 18

*Haliclona sp. 19

${ }^{*}$ Haliclona sp. 20

Adocia sp. 1

*Adocia sp. 2

*Adocia sp. 3

**Adocia sp. 4

Toxadocia sp. 1

$\begin{array}{llll}1 & 1 & 1 & 1\end{array}$

$$
1
$$

$\begin{array}{lll}1 & 1 & 1\end{array}$

1

1

1

$\begin{array}{lllll}1 & 1 & 1 & 1 & 1\end{array}$

1

1

1

(1)

1

1

I

1

1

1

1

1

1

$\begin{array}{lllll} & 1 & 1 & 1 & \\ 1 & & & & \\ & & & & \end{array}$

1

1

11

1

11

1

1

11

1

1

1

1

$\begin{array}{lll} & & 1 \\ 1 & 1 & 1\end{array}$ 1

1 


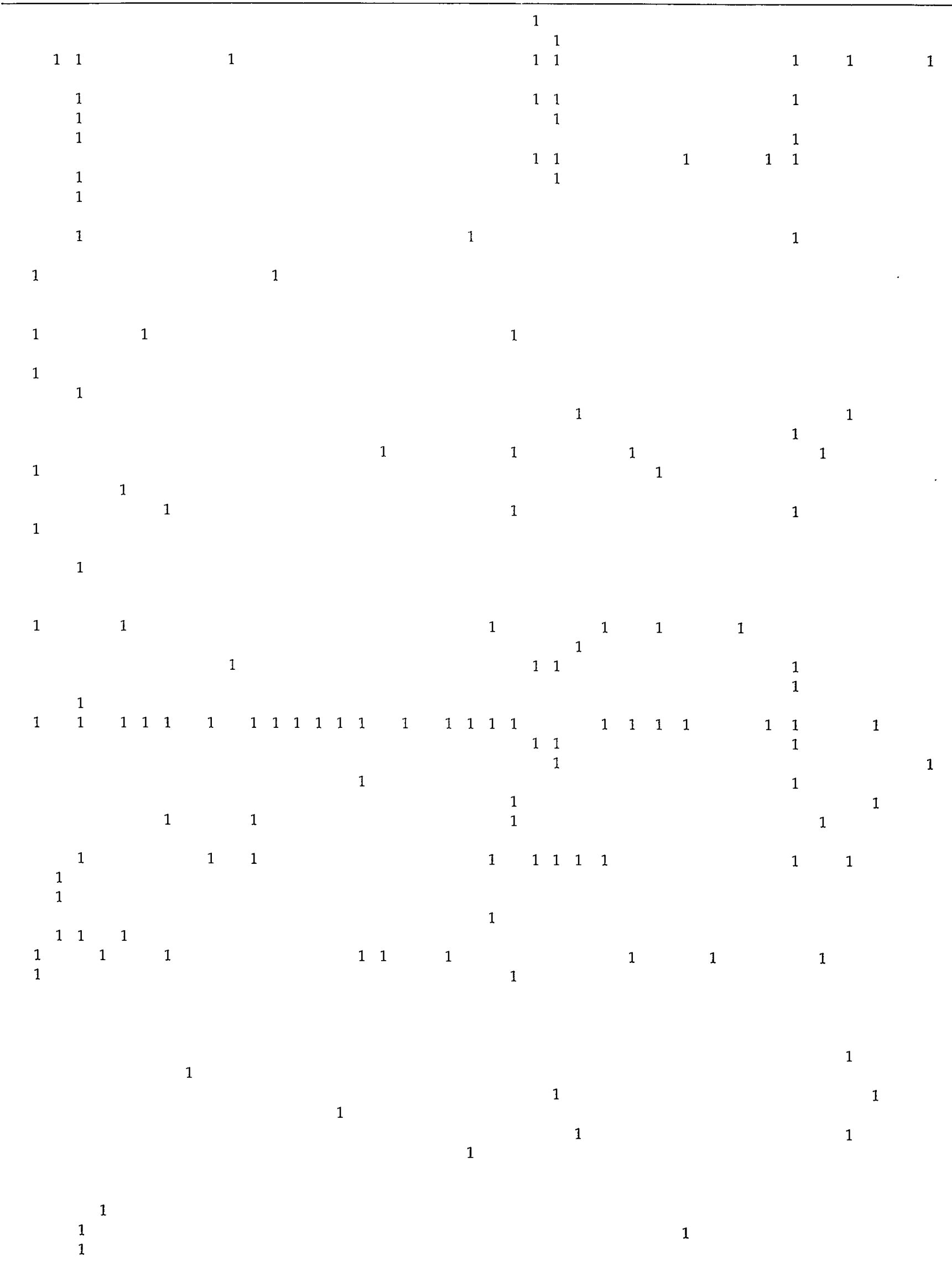


Station \#

Species

$\begin{array}{llllllllllllllll}1 & 2 & 3 & 4 & 5 & 6 & 7 & 8 & 9 & 10 & 11 & 12 & 13 & 14 & 15 & 16\end{array}$

Aka sp. 2

${ }^{*}$ Aka sp. 3

Aka sp. 4

1

1

1

Aka sp. 5

1

Amphimedon lamellata

Amphimedon cf. paraviridis

1

${ }^{*}$ Amphimedon sp. 1

**Amphimedon sp. 2

Niphates cf. nitida

*Niphates sp. 1

Niphates sp. 2

*Niphates sp. 3

Gelliodes fibulata

* Callyspongia sp. 5

**Callyspongia sp. 6

${ }^{*}$ Callyspongia sp. 7

${ }^{*}$ Callyspongia sp. 9

${ }^{*}$ Callyspongia sp. 10

Toxochalina sp. 1

Toxochalina sp. 2

Petrosia sp. 1

*Petrosia sp. 2

*Petrosia sp. 3

Petrosia sp. 4

Xestospongia exigua

Xestospongia cf. testudinaria

${ }^{*}$ Xestospongia sp. 1

Xestospongia sp. 2

**Xestospongia sp. 3

* Oceanapia macrotoxa

${ }^{*}$ Oceanapia cf. ramsayi

*Oceanapia sp. 1

* Oceanapia sp. 2

Oceanapia sp. 3

*Oceanapia sp. 4

Oceanapia sp. 5

*Oceanapia sp. 6

**Oceanapia sp. 7

*Coscinoderma mathezusi

${ }^{*}$ Coscinoderma sp. 1

Hyatella cf. intestinalis

Hyatella sp. 1

Hyrtios cf. erecta

*Hyrtios sp. 1

* Spongia (Australospongia) sp. 1

*Spongia (Heterofibria) sp. 2

${ }^{*}$ Spongia (Spongia) sp. 1

**Aplysinopsis sp. 1

Carteriospongia cf. flabellifera

* Carteriospongia sp. 1

**Carteriospongia sp. 2

${ }^{*}$ Carteriospongia sp. 3

${ }^{*}$ Dysidea cf. herbacea

Dysidea sp. 1

${ }^{*}$ Dysidea sp. 2

${ }^{*}$ Dysidea sp. 3

**Fasciospongia sp. 1

Phyllospongia cf. papyracea

1

1

11

1

1

1

1

1

(1)


Station \#

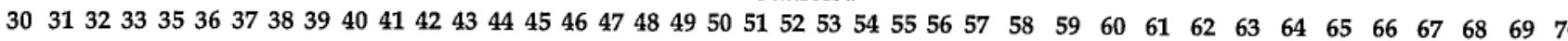

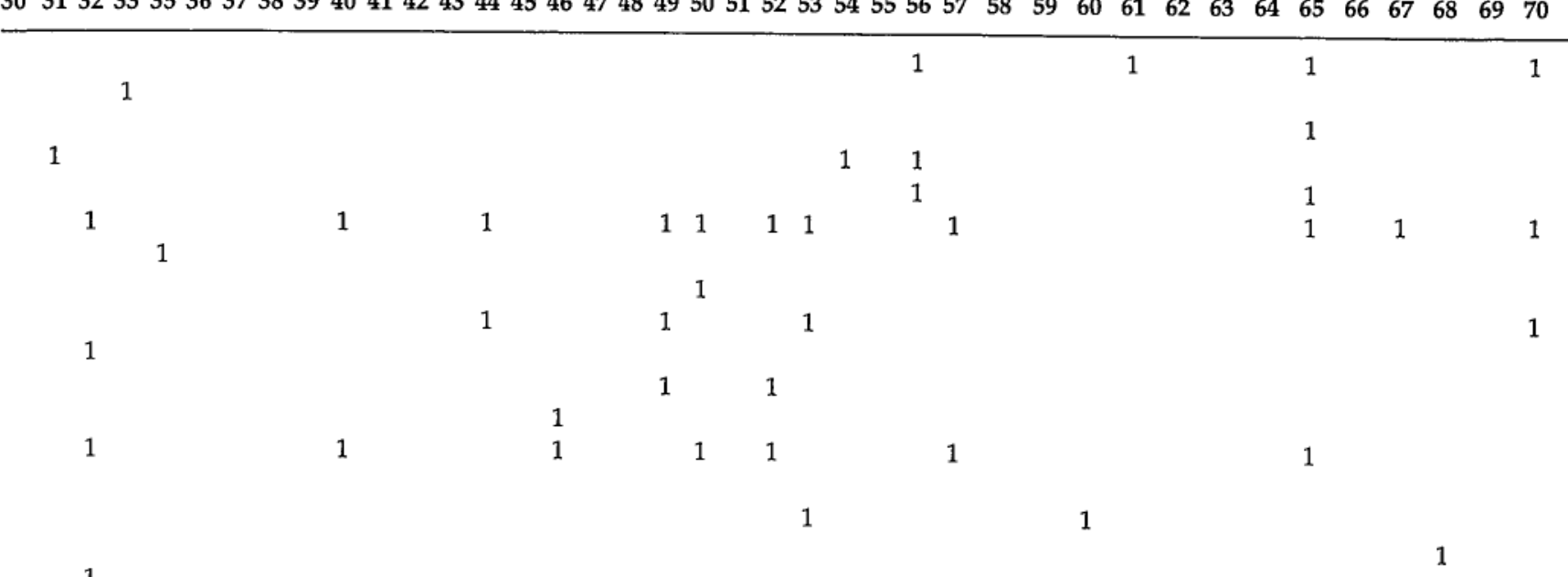

1

11

$\begin{array}{ll}1 & 1 \\ & 1\end{array}$

$\begin{array}{ll}1 & 1 \\ 1 & 1\end{array}$

1

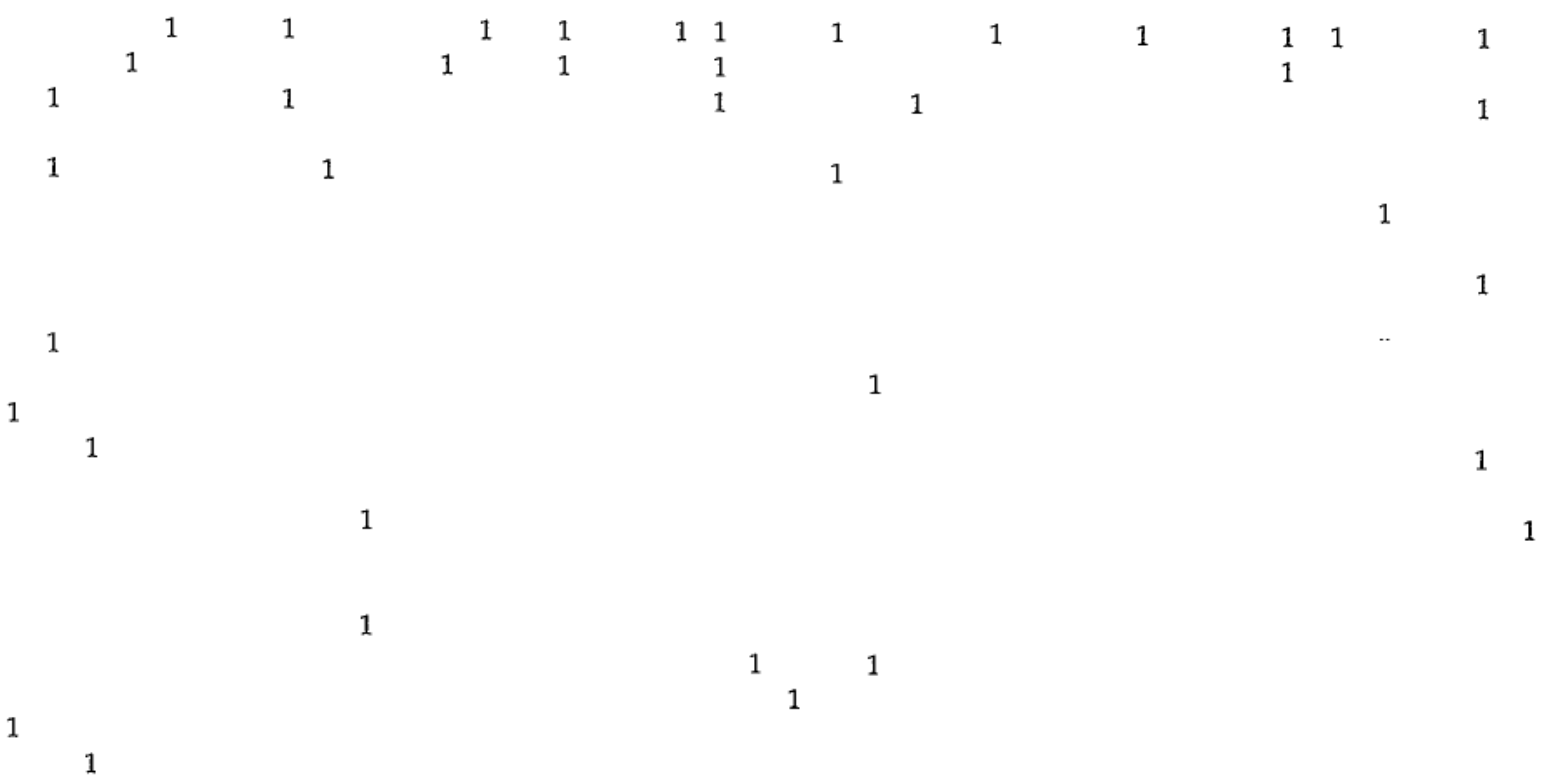

1

1

1

1

1

1

1

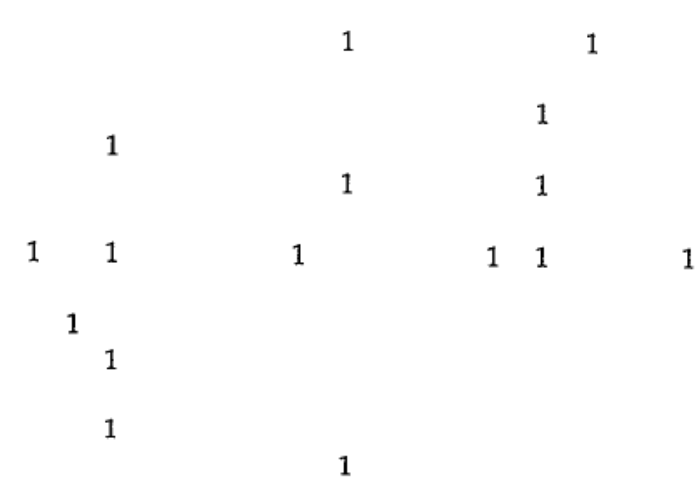


Station \#

Species

$\begin{array}{lllllllllllllllllllllllllllll}1 & 2 & 3 & 4 & 5 & 6 & 7 & 8 & 9 & 10 & 11 & 12 & 13 & 14 & 15 & 16 & 17 & 18 & 19 & 20 & 21 & 22 & 23 & 24 & 25 & 26 & 27 & 28 & 29\end{array}$

*Scalarispongia sp. 1

*Taonura sp. 1

*Taonura sp. 2

*Thorectandra sp. 1

*Aplysilla sp. 1

${ }^{*}$ Chelonaplysilla cf. aurea

${ }^{*}$ Dictyodendrilla sp. 1

*Aplysina sp. 1

${ }^{*}$ Aplysina sp. 2

**Aplysina sp. 3

**Aplysina sp. 4

*Pseudoceratina cf. verrucosa $11 \quad 1 \quad 1$

Pseudoceratina sp. 2

Ianthella basta

Ianthella flabelliformis

**Ianthella labryrinthus

Ianthella cf. reticulata

*Ianthella sp. 1

* Calcarea 1

**Calcarea 2

**Calcarea 3

**Calcarea 4

**Calcarea 5

Total species number per station: 
Station \#

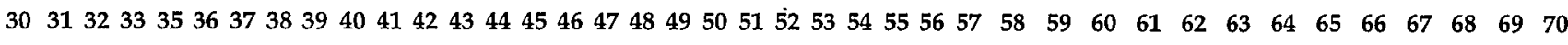
1 1

1

1

$\begin{array}{rrrrrrrr}1 & 1 & & & & & & \\ 1 & 1 & 1 & 1 & 1 & 1 & 1 \\ 1 & & & & & 1 & 1\end{array}$

1 
Appendix 2 Locations, latitudes and Ingitudes of stations from diving expeditions DA1/98 and DA3/99.

\begin{tabular}{|c|c|c|c|c|}
\hline Station & Location & Depth (m) & Latitude & Longitude \\
\hline DA1/98/01 & Dolphin Island & 5.9 & $20^{\circ} 25.85^{\prime} \mathrm{S}$ & $116^{\circ} 52.95^{\prime} \mathrm{E}$ \\
\hline $\mathrm{DA} 1 / 98 / 02$ & Dolphin Island & Intertidal & $20^{\circ} 28.09^{\prime} \mathrm{S}$ & $116^{\circ} 51.91^{\prime} \mathrm{E}$ \\
\hline $\mathrm{DA} 1 / 98 / 03$ & Legendre Island & 9.1 & $20^{\circ} 24.32^{\prime} \mathrm{S}$ & $116^{\circ} 56.11^{\prime} \mathrm{E}$ \\
\hline $\mathrm{DA} 1 / 98 / 04$ & Legendre Island & $9.0-11.0$ & $20^{\circ} 24.32^{\prime} \mathrm{S}$ & $116^{\circ} 56.11 ' \mathrm{E}$ \\
\hline DA1/98/05 & Legendre Island & Intertidal & $20^{\circ} 25.38^{\prime} \mathrm{S}$ & $116^{\circ} 57.51^{\prime} \mathrm{E}$ \\
\hline $\mathrm{DA} 1 / 98 / 06$ & Hauy Island & $2.0-3.0$ & $20^{\circ} 25.72^{\prime} \mathrm{S}$ & $116^{\circ} 57.58^{\prime} \mathrm{E}$ \\
\hline DA1/98/07 & Gidley Island & Intertidal & $20^{\circ} 28.01^{\prime} S$ & $116^{\circ} 47.72^{\prime} \mathrm{E}$ \\
\hline $\mathrm{DA} 1 / 98 / 08$ & Angel Island & $2.0-2.4$ & $20^{\circ} 29.18^{\prime} \mathrm{S}$ & $116^{\circ} 47.71^{\prime} \mathrm{E}$ \\
\hline DA1/98/09 & Angel Island & 4.6 & $20^{\circ} 28.69^{\prime} \mathrm{S}$ & $116^{\circ} 47.95^{\prime} \mathrm{E}$ \\
\hline $\mathrm{DA} 1 / 98 / 10$ & Angel Island & Intertidal & $20^{\circ} 28.41^{\prime} \mathrm{S}$ & $116^{\circ} 48.48^{\prime} \mathrm{E}$ \\
\hline $\mathrm{DA} 1 / 98 / 11$ & Dolphin Island & Intertidal & $20^{\circ} 30.25^{\prime} S$ & $116^{\circ} 49.33^{\prime} \mathrm{E}$ \\
\hline DA1/98/12 & Angel Island & $4.0-5.0$ & $20^{\circ} 30.20^{\prime} S$ & $116^{\circ} 47.25^{\prime} \mathrm{E}$ \\
\hline $\mathrm{DA} 1 / 98 / 13$ & Hamersley Shoal & $7.0-8.0$ & $20^{\circ} 23.20^{\prime} \mathrm{S}$ & $116^{\circ} 46.69^{\prime} \mathrm{E}$ \\
\hline DA1/98/14 & Unnamed Island & Intertidal & $20^{\circ} 26.58^{\prime} S$ & $116^{\circ} 48.79^{\prime} \mathrm{E}$ \\
\hline DA1/98/15 & Legendre Island & $15.0-16.0$ & $20^{\circ} 21.14 ' s$. & $116^{\circ} 50.58^{\prime} \mathrm{E}$ \\
\hline DA1/98/16 & Hamersley Shoal & 16.4 & $20^{\circ} 23.24^{\prime} \mathrm{S}$ & $116^{\circ} 47.08^{\prime} \mathrm{E}$ \\
\hline $\mathrm{DA} 1 / 98 / 17$ & Wilcox Island & Intertidal & $20^{\circ} 27.09^{\prime} \mathrm{S}$ & $116^{\circ} 50.44^{\prime} \mathrm{E}$ \\
\hline $\mathrm{DA} 1 / 98 / 18$ & Haüy Island & $9.0-10.0$ & $20^{\circ} 26.40^{\prime} S$ & $116^{\circ} 58.63^{\prime} \mathrm{E}$ \\
\hline $\mathrm{DA} 1 / 98 / 19$ & Haüy Island & 2.7 & $20^{\circ} 26.62^{\prime} S$ & $116^{\circ} 58.39^{\prime} \mathrm{E}$ \\
\hline $\mathrm{DA} 1 / 98 / 20$ & Collier Rocks & Intertidal & $20^{\circ} 24.81^{\prime} \mathrm{S}$ & $116^{\circ} 50.68^{\prime} \mathrm{E}$ \\
\hline $\mathrm{DA} 1 / 98 / 21$ & Delambre Island & $11.0-13.0$ & $20^{\circ} 25.70^{\prime} \mathrm{S}$ & $117^{\circ} 04.22^{\prime} \mathrm{E}$ \\
\hline DA1/98/22 & Delambre Island & $3.0-4.0$ & $20^{\circ} 25.91^{\prime} \mathrm{S}$ & $117^{\circ} 03.65^{\prime} \mathrm{E}$ \\
\hline $\mathrm{DA} 1 / 98 / 23$ & Dolphin Island & Intertidal & $20^{\circ} 29.10^{\prime} \mathrm{S}$ & $116^{\circ} 52.22^{\prime} \mathrm{E}$ \\
\hline DA1/98/24 & Dolphin Island & 5.0 & $20^{\circ} 28.87^{\prime} \mathrm{S}$ & $116^{\circ} 52.38^{\prime} \mathrm{E}$ \\
\hline $\mathrm{DA} 1 / 98 / 25$ & Keast Island & Intertidal & $20^{\circ} 23.97 ' \mathrm{~S}$ & $116^{\circ} 49.52^{\prime} \mathrm{E}$ \\
\hline DA1/98/26 & Madeleine Shoals & $19.0-22.0$ & $20^{\circ} 19.34^{\prime} \mathrm{S}$ & $116^{\circ} 50.45^{\prime} \mathrm{E}$ \\
\hline $\mathrm{DA} 1 / 98 / 27$ & Legendre Island & $13.0-16.0$ & $20^{\circ} 24.04^{\prime} \mathrm{S}$ & $116^{\circ} 55.04^{\prime} \mathrm{E}$ \\
\hline $\mathrm{DA} 1 / 98 / 28$ & Dolphin Island & Intertidal & $20^{\circ} 25.77^{\prime} \mathrm{S}$ & $116^{\circ} 52.68^{\prime} \mathrm{E}$ \\
\hline $\mathrm{DA} 1 / 98 / 29$ & Legendre Island & $3.0-4.0$ & $20^{\circ} 24.57^{\prime} S$ & $116^{\circ} 53.71^{\prime} \mathrm{E}$ \\
\hline DA1/98/30 & Burrup Peninsula & 11.0 & $20^{\circ} 31.59^{\prime} \mathrm{S}$ & $116^{\circ} 51.09^{\prime} \mathrm{E}$ \\
\hline $\mathrm{DAI} / 98 / 31$ & Searipple Passage & Intertidal & $20^{\circ} 31.23^{\prime} \mathrm{S}$ & $116^{\circ} 51.18^{\prime} \mathrm{E}$ \\
\hline $\mathrm{DA} 1 / 98 / 32$ & Legendre Island & $9.0-11.0$ & $20^{\circ} 23.52 ' S$ & $116^{\circ} 54.11^{\prime} \mathrm{E}$ \\
\hline DA1/98/33 & Angel Island & $7.0-8.0$ & $20^{\circ} 27.96 ' S$ & $116^{\circ} 49.69^{\prime} \mathrm{E}$ \\
\hline $\mathrm{DA} 1 / 98 / 35$ & Legendre Island & Intertidal & $20^{\circ} 23.62^{\prime} \mathrm{S}$ & $116^{\circ} 51.96^{\prime} \mathrm{E}$ \\
\hline DA3/99/36 & N Malus Island & 8.5 & $20^{\circ} 30.63 ' S$ & $116^{\circ} 38.79^{\prime} \mathrm{E}$ \\
\hline $\mathrm{DA} 3 / 99 / 37$ & NW Malus Island & 3.5 & $20^{\circ} 30.63^{\prime} \mathrm{S}$ & $116^{\circ} 38.79^{\prime} \mathrm{E}$ \\
\hline DA3/99/38 & N Malus Island & Intertidal & $20^{\circ} 30.90^{\prime} \mathrm{S}$ & $116^{\circ} 40.22^{\prime} \mathrm{E}$ \\
\hline $\mathrm{DA} 3 / 99 / 39$ & NNE Brigadier Island & Intertidal & $20^{\circ} 25.41^{\prime} \mathrm{S}$ & $116^{\circ} 37.58^{\prime} \mathrm{E}$ \\
\hline DA3/99/40 & W Brigadier Island & 8.0 & $20^{\circ} 26.66^{\prime} S$ & $116^{\circ} 36.51^{\prime} \mathrm{E}$ \\
\hline $\mathrm{DA} 3 / 99 / 41$ & S Georgeff Reef & 8.0 & $20^{\circ} 29^{\prime} 34^{\prime} \mathrm{S}$ & $116^{\circ} 36.80^{\prime} \mathrm{E}$ \\
\hline DA3/99/42 & Georgeff Reef & Intertidal & $20^{\circ} 29.34^{\prime} \mathrm{S}$ & $116^{\circ} 36.80^{\prime} \mathrm{E}$ \\
\hline $\mathrm{DA} 3 / 99 / 43$ & Sailfish Reef, NW Rosemary Island & 11.0 & $20^{\circ} 27.76^{\prime} \mathrm{S}$ & $116^{\circ} 34.19^{\prime} \mathrm{E}$ \\
\hline $\mathrm{DA} 3 / 99 / 44$ & SE Gordon Point, Rosemary Island & $5.0-6.0$ & $20^{\circ} 29.59^{\prime} \mathrm{S}$ & $116^{\circ} 34.45^{\prime} \mathrm{E}$ \\
\hline $\mathrm{DA} 3 / 99 / 45$ & E Tish Point, Rosemary Island & Intertidal & $20^{\circ} 29.67 \mathrm{~S}$ & $116^{\circ} 35.89^{\prime} \mathrm{E}$ \\
\hline DA3/99/46 & NW Kendrew Island & 5.0 & $20^{\circ} 28.60^{\prime} \mathrm{S}$ & $116^{\circ} 31.98^{\prime} \mathrm{E}$ \\
\hline $\mathrm{DA} 3 / 99 / 47$ & NW Kendrew Island & 4.0 & $20^{\circ} 28.94^{\prime} \mathrm{S}$ & $116^{\circ} 32.52 ' \mathrm{E}$ \\
\hline DA3/99/48 & N Goodwyn Island & Intertidal & $20^{\circ} 32.00^{\prime} \mathrm{S}$ & $116^{\circ} 32.42^{\prime} \mathrm{E}$ \\
\hline $\mathrm{DA} 3 / 99 / 49$ & S Goodwyn Island & 5.0 & $20^{\circ} 32.40^{\prime \prime} \mathrm{S}$ & $116^{\circ} 32.61^{\prime} \mathrm{E}$ \\
\hline DA3/99/50 & SE Bare Rock & 15.0 & $20^{\circ} 32.84^{\prime} \mathrm{S}$ & $116^{\circ} 26.73^{\prime} \mathrm{E}$ \\
\hline $\mathrm{DA} 3 / 99 / 51$ & N Enderby Island & Intertidal & $20^{\circ} 35.20^{\prime} \mathrm{S}$ & $116^{\circ} 30.91^{\prime} \mathrm{E}$ \\
\hline DA3/99/52 & NW Roly Rock & 15.0 & $20^{\circ} 29.70^{\prime} S$ & $116^{\circ} 30.17^{\prime} \mathrm{E}$ \\
\hline $\mathrm{DA} 3 / 99 / 53$ & NE Enderby Island & 5.0 & $20^{\circ} 34.54^{\prime} \mathrm{S}$ & $116^{\circ} 34.58^{\prime} \mathrm{E}$ \\
\hline DA3/99/54 & E Enderby Island & Intertidal & $20^{\circ} 36.22 ' \mathrm{~S}$ & $116^{\circ} 33.06^{\prime} \mathrm{E}$ \\
\hline $\mathrm{DA} 3 / 99 / 55$ & Between Enderby \& West Lewis Islands & $17.0-18.0$ & $20^{\circ} 35.15^{\prime} \mathrm{S}$ & $116^{\circ} 35.62^{\prime} \mathrm{E}$ \\
\hline $\mathrm{DA} 3 / 99 / 56$ & NW Eaglehawk Island & 9.0 & $20^{\circ} 38.99^{\prime} \mathrm{S}$ & $116^{\circ} 26.21^{\prime} \mathrm{E}$ \\
\hline $\mathrm{DA} 3 / 99 / 57$ & NE North West Reefs & 9.0 & $20^{\circ} 37.70^{\prime} \mathrm{S}$ & $116^{\circ} 25.09^{\prime} \mathrm{E}$ \\
\hline $\mathrm{DA} 3 / 99 / 58$ & Bay NNE of Enderby Island & 3.5 & $20^{\circ} 34.40^{\prime} \mathrm{S}$ & $116^{\circ} 33.44^{\prime} \mathrm{E}$ \\
\hline $\mathrm{DA} 3 / 99 / 59$ & Bay NNW of Enderby Island & Intertidal & $20^{\circ} 33.95^{\prime} \mathrm{S}$ & $116^{\circ} 38.33^{\prime} \mathrm{E}$ \\
\hline $\mathrm{DA} 3 / 99 / 60$ & Bay N West Lewis Island & 2.5 & $20^{\circ} 32.88^{\prime} \mathrm{S}$ & $116^{\circ} 39.52^{\prime} \mathrm{E}$ \\
\hline $\mathrm{DA} 3 / 99 / 61$ & E West Lewis Island & 5.0 & $20^{\circ} 34.69^{\prime} \mathrm{S}$ & $116^{\circ} 39.70^{\prime} \mathrm{E}$ \\
\hline $\mathrm{DA} 3 / 99 / 62$ & Bay S East Lewis Island & Intertidal & $20^{\circ} 37.50^{\prime} \mathrm{S}$ & $116^{\circ} 39.18^{\prime} \mathrm{E}$ \\
\hline $\mathrm{DA3} / 99 / 63$ & Bay SW end of East Lewis Island & Intertidal & $20^{\circ} 37.47^{\prime} \mathrm{S}$ & $116^{\circ} 38.25^{\prime} \mathrm{E}$ \\
\hline DA3/99/64 & S West Lewis Island & $5.0-5.3$ & $20^{\circ} 36.65^{\prime} \mathrm{S}$ & $116^{\circ} 37.95^{\prime} \mathrm{E}$ \\
\hline $\mathrm{DA} 3 / 99 / 65$ & SW Rocky Head, Enderby Island & 14.0 & $20^{\circ} 37.11 ' S$ & $116^{\circ} 26.78^{\prime} \mathrm{E}$ \\
\hline $\mathrm{DA} 3 / 99 / 66$ & Mangrove Creek, S Enderby Island & Intertidal & $20^{\circ} 36.70^{\prime} \mathrm{S}$ & $116^{\circ} 31.29^{\prime} \mathrm{E}$ \\
\hline $\mathrm{DA} 3 / 99 / 67$ & N Nelson Rocks & 17.0 & $20^{\circ} 26^{\prime} 51^{\prime} \mathrm{S}$ & $116^{\circ} 40.26^{\prime} \mathrm{E}$ \\
\hline $\mathrm{DA} 3 / 99 / 68$ & NE Nelson Rocks & 6.5 & $20^{\circ} 28.00^{\prime} \mathrm{S}$ & $116^{\circ} 39.71^{\prime} \mathrm{E}$ \\
\hline $\mathrm{DA} 3 / 99 / 69$ & Pipeline & $14.0-19.0$ & $20^{\circ} 24.48^{\prime} \mathrm{S}$ & $116^{\circ} 46.31^{\prime} \mathrm{E}$ \\
\hline $\mathrm{DA} 3 / 99 / 70$ & NE Nelson Rocks & 6.0 & $20^{\circ} 27.44 ' \mathrm{~S}$ & $116^{\circ} 39.59^{\prime} \mathrm{E}$ \\
\hline
\end{tabular}




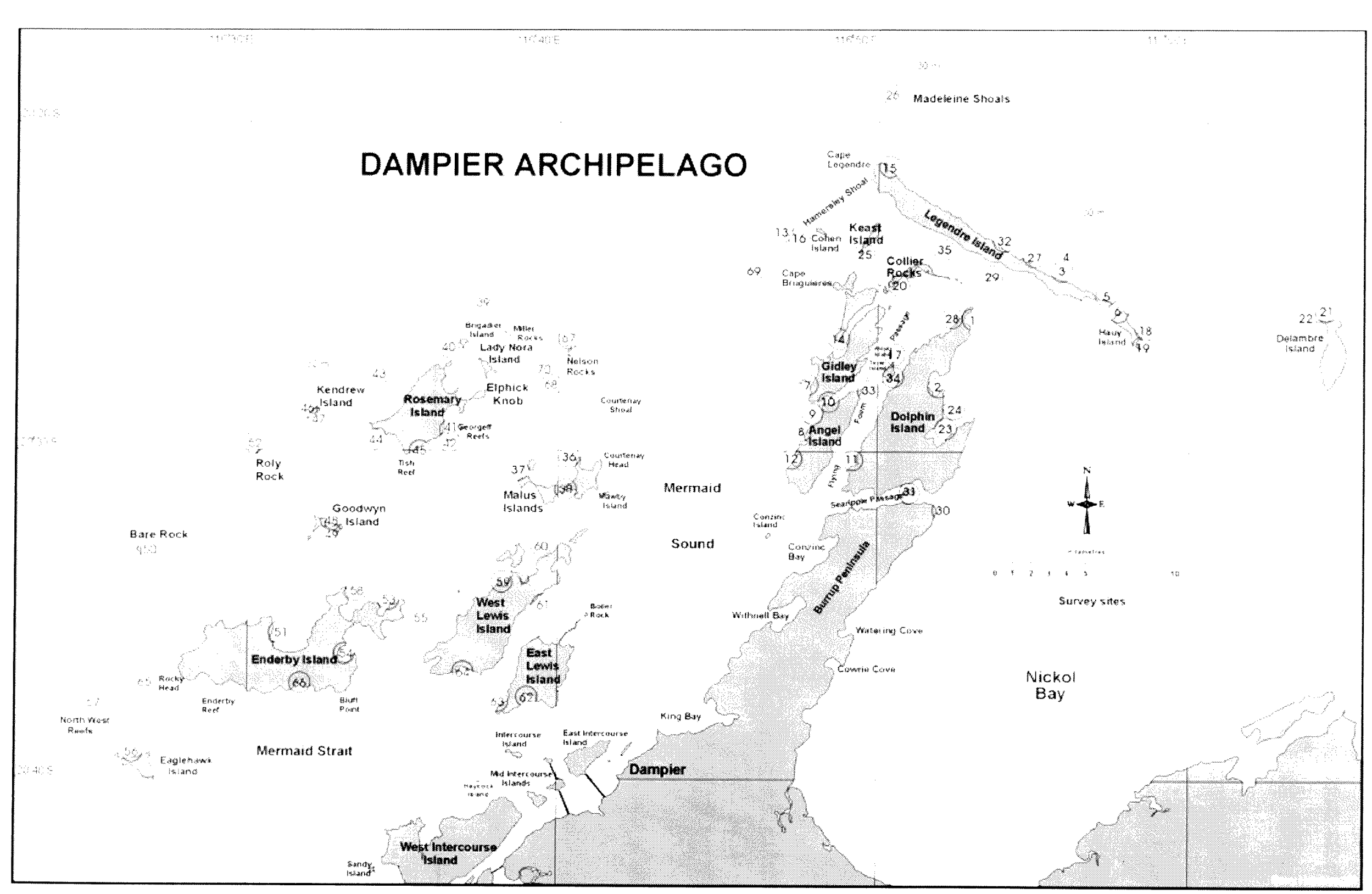




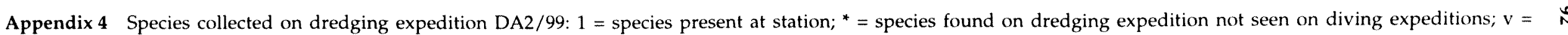
image only.

\begin{tabular}{|c|c|c|c|c|c|c|c|c|c|c|c|c|c|c|c|c|c|c|c|c|c|c|c|c|c|c|c|c|c|c|c|}
\hline \multirow[b]{2}{*}{ Species } & \multirow[b]{2}{*}{1} & \multirow[b]{2}{*}{2} & \multirow[b]{2}{*}{3} & \multirow[b]{2}{*}{4} & \multirow[b]{2}{*}{5} & \multirow[b]{2}{*}{6} & \multirow[b]{2}{*}{7} & \multirow[b]{2}{*}{8} & \multirow[b]{2}{*}{9} & \multirow[b]{2}{*}{10} & & & Str & & & & & & & & & & & & & & & & & & \\
\hline & & & & & & & & & & & 13 & 18 & 22 & 24 & 31 & 32 & 36 & 37 & 39 & 44 & 50 & 62 & 65 & 67 & 68 & 70 & 73 & 75 & 78 & 84 & 99 \\
\hline *Corticium simplex & & & & & & & & & & & & & & & & & & 1 & & & & & & & & & & & & & \\
\hline * Disyringa cf. nodosa & 1 & & & & & & & & & & & & & 1 & & & & & & & & & 1 & & & & & & & & \\
\hline Penares sp. 1 & & & & 1 & & & & & & & & & & & & & & & & & & & & & & & & & & & \\
\hline *Jaspis sp. 2 & & & & & & & & & & & & & & & & & & & & & & & 1 & & & & & & & & \\
\hline *Geodia sp. 5 & & & & & & & & & & & & & & & & & & 1 & & & & & & & & & & & & & \\
\hline Myriastra cf. clarosa & & & & & & & & & & & & & & & & & & & & & & & 1 & & & & & & & & \\
\hline Cinachyra cf. isis & & & & & & 1 & & & & & & & & & & & & & & & & & & & & & & & & & \\
\hline Cinachyrella sp. 2 & & & & & & & & & & 1 & & & & & & & & & & & & & & & & & & & & & \\
\hline Spirastrella cf. vagabunda & & & & & & & & & 1 & & & & & & & & & & & & & & & & & & & & & & \\
\hline *Caulospongia plicata & & & & 1 & & & & & & & & & & & & & & & & & & & & & & & & & & & \\
\hline Laxotethya dampierensis & & & & 1 & & & & & & & & & & & & & & & & & & & & & & & & & & & \\
\hline 'Tethya sp. 1 & & & & & & & & 1 & & & & & & & & & & & & & & & & & & & & & & & \\
\hline *Tethya sp. 2 & & & & & & & & & & & & & 1 & & & & & & & & & & & & & & & & & & \\
\hline *Xenospongia patelliformis & & & & & 1 & & & & $\mathrm{v}$ & & & $\mathrm{v}$ & & & & & & & & & & & & & & & & & 1 & & \\
\hline *Polymastia sp. 4 & & & & & & & & & & & & & & & & 1 & & & & & & & & & & & & & & & \\
\hline Amorphinopsis cf. sacciformis & & & & & & & & & & & & & & & & & & & & & & & 1 & & & & & & & & \\
\hline Axinella cf. aruensis & & & & & & & & & & & & & & & 1 & & & & & & & & & & & & & & & & \\
\hline Axinella cf. carteri & & & & & & & & & & & & & & & & & & 1 & & & & & & & & & & & & & \\
\hline *Axinella sp. 3 & & & & & 1 & & & & & & & & & & & & & & & & & & & & & & & & & & \\
\hline${ }^{*}$ Axinella sp. 4 & & & & & & & & 1 & & & & & & & & & & & & & & & & & & & & & & & \\
\hline Reniochalina stalagmites & & & & & & & & 1 & 1 & & & & & & & & & & & & & & & & & 1 & & & & & \\
\hline Reniochalina sp. 1 & & & & 1 & & & & & 1 & & & & & & & & & & & & & & & & & & & & & & \\
\hline Reniocialina? sp. 2 & & & & & & & & 1 & & & & & & & & & & & & & & & & & & & & & & & 1 \\
\hline Topsentia halichondroides & & & & & & & & & & & & & & & & & & & & & & & & & & & & & & 1 & \\
\hline Higginsia cf. scabra & & & & 1 & & & & & & & & & & & & & & & & & & & & & & & & & & & \\
\hline Myrmekioderma granulata & & & & & & & & & & & 1 & & & & & & & 1 & & & & & & & & & 1 & 1 & & & \\
\hline Amphinomia sulphurea & & & & & & & & & & & 1 & & & & & & & & & & & & & & & & & & & & \\
\hline Ceratopsion axifera & & & & & & & & 1 & & & & & & & & & & & & & & & & & & & & & & & \\
\hline Echinodictyum cancellatum & & & & & & & & 1 & 1 & $\mathrm{v}$ & & & & & & & & & & & & & & & & & & & & & \\
\hline Echinodictyum clathrioides & & & & 1 & & 1 & & & & 1 & & & & & & & & & & & & & & & & & & & & & \\
\hline "Echinodictyum conulosum & & & & & & & & & & & 1 & & & & & & & & & & & & & & & & & & & & \\
\hline Echinodictyum mesenterinum & & & & & & & & & 1 & & & & & & & & & & & & & & & & & & & & & & \\
\hline Ectyoplasia tabula & & & & & & & & & & 1 & & & & & & & & & & & $\mathrm{v}$ & $\mathrm{v}$ & & & & & & & & & 1 \\
\hline Raspailia (Raspailia) cf. phake & lopsi: & & & & & & & & & & & & & & & & & & & & & & & 1 & & & & & & & \\
\hline Raspailia (Raspailia) vestigife & & & & & & & & 1 & & & & & & & & & & & & & & & & & & & & & & & \\
\hline Thrinacophora cervicornis & & & & & & & & 1 & & & & & & & & & & & & & & & & & & & & & & & \\
\hline Trikentrion flabelliforme & & & & & & 1 & 1 & & & & & & & & & & & & & & & 1 & & & & & & & & & 1 \\
\hline *Coelosphaera sp. 1 & & & & & & & & & & & & & & & & & & & & & & & 1 & & & & & & & & \\
\hline *Ectyodoryx sp. 1 & & & & & & 1 & & & & & & & & & & & & & & & & & & & & & & & & & \\
\hline *Desmacidon sp. 1 & & & & & & & & & & & 1 & & & & & & & & & & & & & & & & & & & & \\
\hline Iotrochota sp. 1 & & & & & & & & & & & & & & & & & & 1 & & & & & & & & & & & & & \\
\hline "Iotrochota sp. 2 & & & & & & & & & & & 1 & & & & & & & & & & & & & & & & & & & & \\
\hline
\end{tabular}


Clathria (Thalysias) reinwardt

Mycale cf. phyllophila

Mycale sp. 3

Haliclona sp. 15

*Haliclona sp. 16

*Haliclona sp. 17

*Arenosclera sp. 1

* Callyspongia cf. subarmigera

*Callyspongia sp. 8

Xestospongia cf. testudinaria

'Xestospongia sp. 4

Oceanapia sp. 3

Oceanapia sp. 7

*Oceanapia sp. 12

Hyatella of intestinalis

* Spongia (Heterofibria) sp. 1

${ }^{*}$ Euryspongia sp. 2

Fasciospongia sp. 1

*Fenestraspongia sp. 1

Thorectandra sp. 1

Ircinia sp. 1

*Psammocinia sp. 6

*Psammocinia sp. 7

*Sarcotragus sp. 2

*Sarcotragus sp. 3

Pseudoceratina cf. verrucosa

Pseudoceratina sp. 2

Ianthella basta

Ianthella flabelliformis

Ianthella cf. reticulata

Ianthella sp. 1

Class Calcarea 7

Total species number per station: 
Appendix 5 Species collected on workshop expedition DA4/00: 1 = species present at station; ${ }^{*}=$ species collected by $\mathrm{DA} 4 / 00$ not seen on previous three expeditions. (Stations $39 \& 41$ not surveyed by author.)

\begin{tabular}{|c|c|c|c|c|c|c|c|c|c|c|c|c|c|c|c|c|c|c|c|}
\hline \multirow[b]{2}{*}{ Species } & \multirow[b]{2}{*}{1} & \multirow[b]{2}{*}{3} & \multirow[b]{2}{*}{4} & \multirow[b]{2}{*}{6} & \multirow[b]{2}{*}{8} & \multirow[b]{2}{*}{9} & \multirow[b]{2}{*}{10} & & Stati & tion \# & & & & & & & & & \\
\hline & & & & & & & & 12 & 14 & 15 & 16 & 17 & 18 & 19 & 22 & 23 & 27 & 39 & 41 \\
\hline Penares sp. 1 & & & 1 & & & & 1 & & & 1 & & & & & & & & & \\
\hline Rhabdastrella globostellata & & & 1 & & & & & & & & & & & & & 1 & & & \\
\hline Cinachyra cf. isis & & & & & 1 & & 1 & 1 & & & & & & & & & & & \\
\hline Cinachyra sp. 1 & & & & & & 1 & & & & & & & & & & & & & \\
\hline Cinachyrella cf. tenuiviolacea & & & & & & & & & & & 1 & & & & & & & & \\
\hline${ }^{*}$ Cinachyrella sp. 1 & & & & & & 1 & & & & & & & & & & & & & \\
\hline Tetilla sp. 1 & & & & & & 1 & & & & & & & & & & & & & \\
\hline Chondrilla sp. 1 & & & & & & & 1 & & & & & & & & & & & & \\
\hline Spirastrella cf. inconstans & & & & & & & & & & 1 & & & & & & & & & \\
\hline Spirastrella cf. vagabunda & & & & & & 1 & & & & & & & & & & & & & \\
\hline Spirastrella sp. 3 & & & & & & 1 & & & & & & 1 & & & 1 & & & & \\
\hline Spirastrella sp. 4 & & & & & & & & & 1 & & & & & & & & & & \\
\hline Cliona dissimilis & & & & & & & & & & & & & & & & & 1 & & \\
\hline Cliona orientalis & & & 1 & & & & 1 & & & & & & & & & & & & \\
\hline Pione velans & & & 1 & & & & & & & & & & & & & & & & \\
\hline *Timea cf. centrifera & & 1 & & & & & & & & & & & & & & & & & \\
\hline Aaptos sp. 1 & & & & & 1 & & & & 1 & & & & & & & & 1 & & \\
\hline Laxosuberites proteus & & & & & & & & & 1 & 1 & 1 & & & & & & & & \\
\hline Theonella discifera & & & & & & & & 1 & 1 & 1 & & & & & & & & & \\
\hline Theonella levior & & & & & & & & 1 & 1 & 1 & & & & & & & & & \\
\hline${ }^{*}$ Axinella sp. 2 & & & & & & & & & & & 1 & & & & & & & & \\
\hline Cymbastela vespertina & & & & & & & & & & & 1 & & & & 1 & & & & \\
\hline Reniochalina stalagmites & & & & & & & & & & & 1 & 1 & & & & & & & \\
\hline Reniochalina sp. 1 & & & & & 1 & & & & & & 1 & & & & & & & & \\
\hline Reniochalina? sp. 2 & & & & & & 1 & & & & & & 1 & & & & & & & \\
\hline *Rhaphoxya? cf. rugolineata & & & & & & & & & & & & & & & & & 1 & & \\
\hline *Rhaphoxya sp. 1 & & & & 1 & & & & & & & & & 1 & & & & & & \\
\hline *Stylissa flabelliformis & & & & & & & & & & & & & & & 1 & & & & \\
\hline Amorphinopsis cf. sacciformis & & & & & & & & & & & & & & 1 & & & & & \\
\hline Halichondria cf. bergquistae & & & & & & & & & & & & & & & & & & 1 & \\
\hline *Halichondria vansoesti & & & & & & & & & & & & 1 & 1 & & & & & & \\
\hline *Hymeniacidon cf. gracilis & & & & & & & & & & & & 1 & & & & & & & \\
\hline Hymeniacidon cf. hapalia & & & & & & & & & & 1 & & & & & & & & & \\
\hline Hymeniacidon sp. 2 & & & & & & & & & & & 1 & & & & & & & & \\
\hline Topsentia halichondroides & & & & & & & & & & & 1 & & & & & & & & \\
\hline Higginsia cf. scabra & & & & & & & & & & & & & & & 1 & & 1 & & \\
\hline Amphinomia sulphurea & & & & & & & 1 & & & & & & & & & & & & \\
\hline Ceratopsion axifera & & & & & & & & & & & & 1 & & & & & & & \\
\hline Echinodictyum cancellatum & & & & & & 1 & & & & & & & & & & . & & & \\
\hline Echinodictyum clathrioides & & & & & & & & & & & & & & & & & 1 & & \\
\hline Ectyoplasia frondosa & & & & & & & & & & & 1 & & & & & & 1 & & \\
\hline Ectyoplasia tabula & & & & 1 & & & & 1 & & & 1 & & & & & & & & \\
\hline Raspailia (Raspailia) vestigifera & & & & & & & & & & & & 1 & & & & & & & \\
\hline Trikentrion flabelliforme & & & & & & & & & & & & 1 & & & & & & & \\
\hline${ }^{*}$ Chondropsis sp. 1 & & & & & & & & & & & & & & & & & 1 & & \\
\hline Phoriospongia sp. 1 & & & & & & & & & & 1 & & & & & & & & & \\
\hline Phoriospongia sp. 2 & & & & & & & & & & & & & & & & & 1 & & \\
\hline Desmapsamma sp. 1 & & & & & & & & & & & & & 1 & & & & & & \\
\hline *Clathria (Microciona) aceratoobtusa & & & & & & & & & & & & & & 1 & & & & & \\
\hline${ }^{*}$ Clathria (Microciona) sp. 2 & & & & & & & & & & 1 & & & & & & & & & \\
\hline *Clathria (Microciona) sp. 3 & & & & & & & & & & 1 & & & & & & & & & \\
\hline Clathria (Thalysias) abietina & & & & & & 1 & & & & & & 1 & & & & & & & \\
\hline *Clathria (Thalysias) cancellaria & & & & & & & & & & & & 1 & & & & & & & \\
\hline Clathria (Thalysias) lendenfeldi & & & & 1 & & & & & & & & & & & & & & & \\
\hline Clathria (Thalysias) major & & & & & & 1 & & & & & & & & & & & 1 & & \\
\hline Clathria (Thalysias) reinwardti & & 1 & & & 1 & & & & & & & & & & & & & & \\
\hline Clathria (Wilsonella) cf. claviformis & & & & & & & & & & & 1 & & & & & & & & \\
\hline $\begin{array}{l}\text { Echinochalina (Echinochalina) } \\
\text { cf. intermedia }\end{array}$ & & & & & & & & & & & & & & & & & 1 & & 1 \\
\hline Mycale cf. phyllophila & & & & & & & & & & & 1 & 1 & & & & & & & \\
\hline Mycale sp. 1 & & & & 1 & & & & & & & & & & & & & & & \\
\hline
\end{tabular}


Station \#

Species

Mycale sp. 3

Mycale sp. 4

Haliclona amboinensis

Haliclona sp. 4

Haliclona sp. 8

Haliclona sp. 10

Haliclona sp. 11

${ }^{*}$ Haliclona sp. 14

$\begin{array}{lll}14 & 15\end{array}$

$\begin{array}{lllllllll}16 & 17 & 18 & 19 & 22 & 23 & 27 & 39 & 41\end{array}$

Haliclona sp. 15

Haliclona sp. 19

Adocia sp. 1

Adocia sp. 2

Adocia sp. 3

${ }^{*}$ Adocia sp. 5

Toxadocia sp. 1

1

1

Aka sp. 2

Aka sp. 5

Amphimedon lamellata

Amphimedon cf. paraviridis

*Amphimedon sp. 3

Niphates cf. nitida

Niphates sp. 1

Gelliodes fibulata

Arenosclera sp. 1

Callyspongia sp. 7

Callyspongia sp. 9

Toxochalina sp. 1

Toxochalina sp. 2

*Toxochalina sp. 3

Petrosia sp. 1

Petrosia sp. 4

*Strongylophora sp. 1

Xestospongia cf. testudinaria

Xestospongia sp. 1

Xestospongia sp. 4

Oceanapia macrotoxa

Oceanapia sp. 7

*Oceanapia sp. 8

Coscinoderma mathewsi

Coscinoderma sp. 1

Carteriospongia sp. 2

Dysidea sp. 1

Dysidea sp. 2

Dysidea sp. 3

*Dysidea sp. 4

*Dysidea sp. 5

Ircinia sp. 1

Psammocinia cf. bulbosa

Sarcotragus sp. 2

Pseudoceratina cf. verrucosa

Pseudoceratina sp. 2

Ianthella basta

1

Ianthella flabelliformis

* Class Calcarea 6

Class Calcarea 7

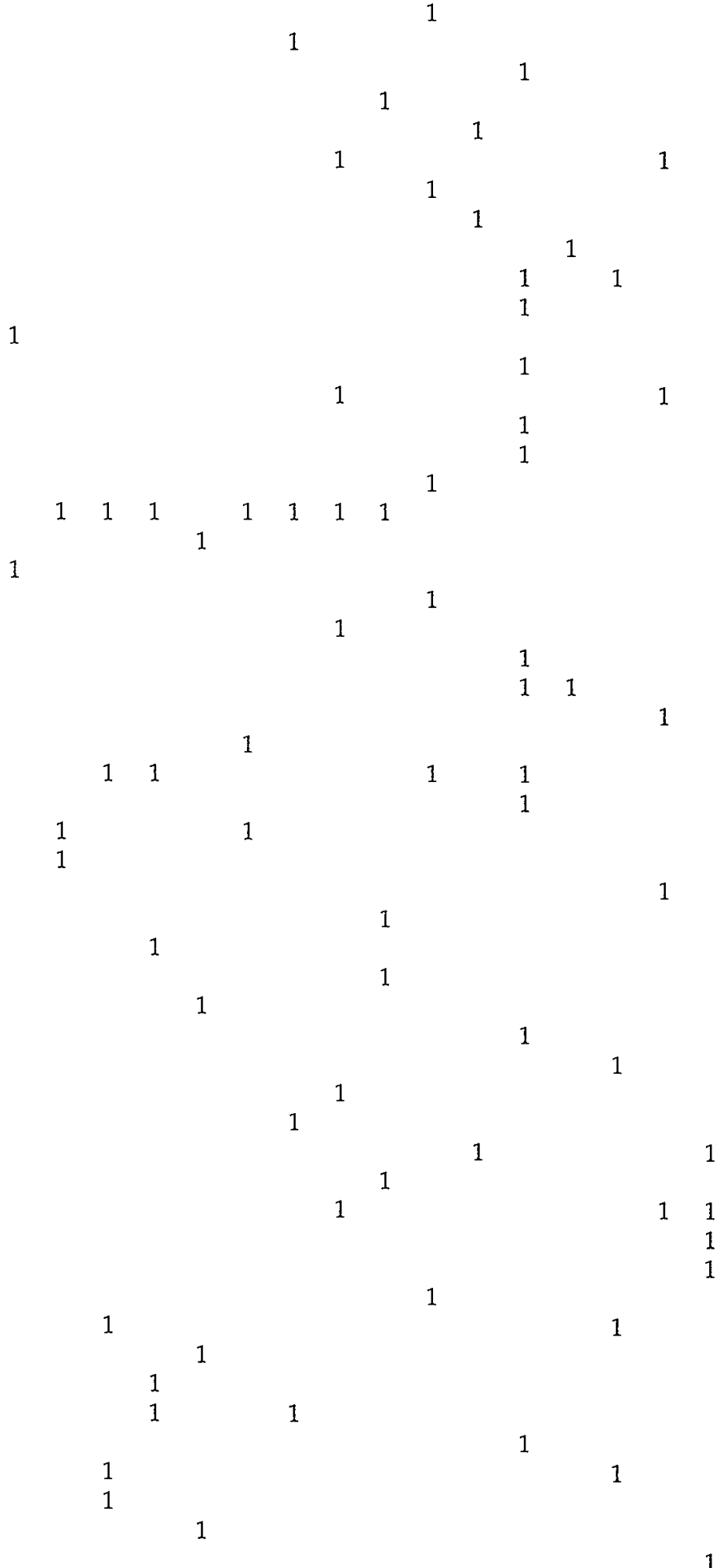

Total species number per station:

$\begin{array}{llllll}1 & 4 & 7 & 10 & 9 & 14\end{array}$

1 
Appendix 6 Locations, latitudes and longitudes of stations from dredging expedition DA2/99.

\begin{tabular}{|c|c|c|c|c|}
\hline Station & Location & Depth (m) & Latitude & Longitude \\
\hline $\mathrm{DA} 2 / 99 / 01$ & N of Phillip Point, Burrup Peninsula & 10.0 & $20^{\circ} 35.32^{\prime} \mathrm{S}$ & $116^{\circ} 43.88^{\prime} \mathrm{E}$ \\
\hline $\mathrm{DA} 2 / 99 / 02$ & E of Courtenay Head Light, Malus Island & 18.0 & $20^{\circ} 29.84^{\prime} \mathrm{S}$ & $116^{\circ} 45.04^{\prime} \mathrm{E}$ \\
\hline $\mathrm{DA} 2 / 99 / 03$ & NW of Cohen Island & 32.0-35.0 Dredge & $20^{\circ} 22.14^{\prime} \mathrm{S}$ & $116^{\circ} 46.13^{\prime} \mathrm{E}$ \\
\hline $\mathrm{DA} 2 / 99 / 04$ & NNW of Cohen Island & 42.0-43.0 Dredge & $20^{\circ} 19.64^{\prime} \mathrm{S}$ & $116^{\circ} 45.75^{\prime} \mathrm{E}$ \\
\hline $\mathrm{DA} 2 / 99 / 05$ & NE of Cape Legendre & 38.0 & $20^{\circ} 19.64^{\prime} \mathrm{S}$ & $116^{\circ} 53.85^{\prime} \mathrm{E}$ \\
\hline $\mathrm{DA} 2 / 99 / 06$ & ESE of Cape Legendre & $33.0-36.0$ & $20^{\circ} 21.69^{\prime} \mathrm{S}$ & $116^{\circ} 52.40^{\prime} \mathrm{E}$ \\
\hline $\mathrm{DA} 2 / 99 / 07$ & E of Cape Legendre & 37.0 & $20^{\circ} 20.90^{\prime} \mathrm{S}$ & $116^{\circ} 57.04^{\prime} \mathrm{E}$ \\
\hline $\mathrm{DA} 2 / 99 / 08$ & NNE of NW tip of Delambre Island & $30.0-31.0$ & $20^{\circ} 22.76^{\prime} \mathrm{S}$ & $117^{\circ} 02.23^{\prime} \mathrm{E}$ \\
\hline $\mathrm{DA} 2 / 99 / 09$ & $\mathrm{~N}$ of $\mathrm{NE}$ corner of Delambre Island & $31.0-34.5$ & $20^{\circ} 20.38^{\prime} \mathrm{S}$ & $117^{\circ} 05.22^{\prime} \mathrm{E}$ \\
\hline $\mathrm{DA} 2 / 99 / 10$ & N of NE corner of Delambre Island & 29.0 & $20^{\circ} 23.97 ' \mathrm{~S}$ & $117^{\circ} 04.82^{\prime} \mathrm{E}$ \\
\hline $\mathrm{DA} 2 / 99 / 12$ & NNW of NW point, Delambre Island & $32-34$ & $20^{\circ} 20.75^{\prime} \mathrm{S}$ & $117^{\circ} 01.16^{\prime} \mathrm{E}$ \\
\hline $\mathrm{DA} 2 / 99 / 13$ & E of Haüy Island & 19.5 & $20^{\circ} 26.52 ' \mathrm{~S}$ & $117^{\circ} 00.50^{\prime} \mathrm{E}$ \\
\hline $\mathrm{DA} 2 / 99 / 15$ & SW of S tip of Legendre Island & 9.5 & $20^{\circ} 27.27^{\prime} \mathrm{S}$ & $116^{\circ} 54.20^{\prime} \mathrm{E}$ \\
\hline $\mathrm{DA} 2 / 99 / 16$ & E of Sloping Point, Burrup Peninsula & 11.5 & $20^{\circ} 31.41^{\prime} \mathrm{S}$ & $116^{\circ} 52.83^{\prime} \mathrm{E}$ \\
\hline $\mathrm{DA} 2 / 99 / 17$ & ESE of Sloping Point, Burrup Peninsula & $16.5-17.0$ & $20^{\circ} 32.99^{\prime} \mathrm{S}$ & $116^{\circ} 54.17^{\prime} \mathrm{E}$ \\
\hline DA2/99/18 & SE of Sloping Point, Burrup Peninsula & $10.0-10.5$ & $20^{\circ} 35.67^{\prime} \mathrm{S}$ & $116^{\circ} 54.97^{\prime} \mathrm{E}$ \\
\hline $\mathrm{DA} 2 / 99 / 19$ & E of Hearson Cove, Burrup Peninsula & $10.0-10.2$ & $20^{\circ} 38.41^{\prime} S$ & $116^{\circ} 52.86^{\prime} \mathrm{E}$ \\
\hline $\mathrm{DA} 2 / 99 / 20$ & S of Sloping Point, Burrup Peninsula & 11.0 & $20^{\circ} 34.30^{\prime} \mathrm{S}$ & $116^{\circ} 52.50^{\prime} \mathrm{E}$ \\
\hline DA2/99/21 & E of Sloping Point, Burrup Peninsula & $16.4-18.0$ & $20^{\circ} 32.25^{\prime} \mathrm{S}$ & $116^{\circ} 58.48^{\prime} \mathrm{E}$ \\
\hline $\mathrm{DA} 2 / 99 / 22$ & WNW of Cape Legendre & $37.0-38.0$ & $20^{\circ} 19.43^{\prime} \mathrm{S}$ & $116^{\circ} 42.61^{\prime} \mathrm{E}$ \\
\hline $\mathrm{DA} 2 / 99 / 23$ & W of Cape Legendre & 37.0 & $20^{\circ} 21.00^{\prime} \mathrm{S}$ & $116^{\circ} 40.39^{\prime} \mathrm{E}$ \\
\hline DA2 $/ 99 / 24$ & $\mathrm{~N}$ of Lady Nora Island & 38.5 & $20^{\circ} 21.79 ' \mathrm{~S}$ & $116^{\circ} 38.05^{\prime} \mathrm{E}$ \\
\hline $\mathrm{DA} 2 / 99 / 25$ & $\mathrm{~N}$ of Rosemary Island & 39.0 & $20^{\circ} 22.29^{\prime} \mathrm{S}$ & $116^{\circ} 35.56^{\prime} \mathrm{E}$ \\
\hline $\mathrm{DA} 2 / 99 / 26$ & NE of Rosemary Island & 34.0 & $20^{\circ} 24.01$ 'S & $116^{\circ} 41.28^{\prime} \mathrm{E}$ \\
\hline $\mathrm{DA} 2 / 99 / 27$ & WSW of Cape Legendre & $33.5-34.0$ & $20^{\circ} 23.29^{\prime} \mathrm{S}$ & $116^{\circ} 43.64^{\prime} \mathrm{E}$ \\
\hline $\mathrm{DA} 2 / 99 / 28$ & WNW of Cape Bruguieres & $30.0-30.5$ & $20^{\circ} 24.07^{\prime} \mathrm{S}$ & $116^{\circ} 43.90^{\prime} \mathrm{E}$ \\
\hline $\mathrm{DA} 2 / 99 / 29$ & W of Cape Bruguieres & $27.0-28.0$ & $20^{\circ} 24.64^{\prime} \mathrm{S}$ & $116^{\circ} 44.05^{\prime} \mathrm{E}$ \\
\hline $\mathrm{DA} 2 / 99 / 30$ & W of Cape Bruguieres & $29.0-30.0$ & $20^{\circ} 25.20^{\prime} S$ & $116^{\circ} 41.74^{\prime} \mathrm{E}$ \\
\hline $\mathrm{DA} 2 / 99 / 31$ & NW of Courtenay Head Light, Malus Island & 11.5 & $20^{\circ} 29.49^{\prime} \mathrm{S}$ & $116^{\circ} 40.61^{\prime} \mathrm{E}$ \\
\hline $\mathrm{DA} 2 / 99 / 32$ & NE of Courtenay Head Light, Malus Island & $15.0-16.0$ & $20^{\circ} 26.95^{\prime} \mathrm{S}$ & $116^{\circ} 44.86^{\prime} \mathrm{E}$ \\
\hline $\mathrm{DA} 2 / 99 / 33$ & NNE of Courtenay Head Light, Malus Island & $18.0-22.0$ & $20^{\circ} 27.41^{\prime} S$ & $116^{\circ} 42.57^{\prime} \mathrm{E}$ \\
\hline $\mathrm{DA} 2 / 99 / 34$ & WSW High Point on is NE of West Lewis Island & $9.0-13.0$ & $20^{\circ} 32.65^{\prime} \mathrm{S}$ & $116^{\circ} 39.14^{\prime} \mathrm{E}$ \\
\hline $\mathrm{DA} 2 / 99 / 35$ & W High Point on is NE of West Lewis Island & $13.0-15.0$ & $20^{\circ} 32.15^{\prime} \mathrm{S}$ & $116^{\circ} 38.86^{\prime} \mathrm{E}$ \\
\hline $\mathrm{DA} 2 / 99 / 36$ & WSW High Point on is NE of West Lewis Island & 13.0 & $20^{\circ} 33.58^{\prime} \mathrm{S}$ & $116^{\circ} 36.87^{\prime} \mathrm{E}$ \\
\hline $\mathrm{DA} 2 / 99 / 37$ & WNW of Marks Point, West Lewis Island & $14.0-15.0$ & $20^{\circ} 36.54^{\prime} \mathrm{S}$ & $116^{\circ} 34.98^{\prime} \mathrm{E}$ \\
\hline $\mathrm{DA} 2 / 99 / 38$ & WSW of Marks Point, West Lewis Island & $11.0-13.0$ & $20^{\circ} 37.47^{\prime} \mathrm{S}$ & $116^{\circ} 35.37^{\prime} \mathrm{E}$ \\
\hline $\mathrm{DA} 2 / 99 / 39$ & ENE of Bluff Point, Enderby Island & $13.0-14.0$ & $20^{\circ} 37.05^{\prime} \mathrm{S}$ & $116^{\circ} 33.86^{\prime} \mathrm{E}$ \\
\hline $\mathrm{DA} 2 / 99 / 40$ & WSW of Bluff Point, Enderby Island & $10.5-11.0$ & $20^{\circ} 37.74^{\prime} \mathrm{S}$ & $116^{\circ} 31.05^{\prime} \mathrm{E}$ \\
\hline $\mathrm{DA} 2 / 99 / 41$ & N of Rocky Head, Enderby Island & $16.0-17.4$ & $20^{\circ} 35.63^{\prime} \mathrm{S}$ & $116^{\circ} 28.07^{\prime} \mathrm{E}$ \\
\hline $\mathrm{DA} 2 / 99 / 42$ & SW of SW Point of Goodwyn Island & $14.0-16.0$ & $20^{\circ} 34.16^{\prime} \mathrm{S}$ & $116^{\circ} 30.11^{\prime} \mathrm{E}$ \\
\hline $\mathrm{DA} 2 / 99 / 43$ & WNW of SW Point of Goodwyn Island & $21.0-22.0$ & $20^{\circ} 31.60^{\prime} \mathrm{S}$ & $116^{\circ} 29.03^{\prime} \mathrm{E}$ \\
\hline $\mathrm{DA} 2 / 99 / 44$ & W of SW lip of Goodwyn Island & $22.0-23.0$ & $20^{\circ} 32.71^{\prime} \mathrm{S}$ & $116^{\circ} 27.57^{\prime} \mathrm{E}$ \\
\hline $\mathrm{DA} 2 / 99 / 45$ & WSW of SW lip of Goodwyn Island & $22.0-27.0$ & $20^{\circ} 34.35^{\prime} \mathrm{S}$ & $116^{\circ} 25.27^{\prime} \mathrm{E}$ \\
\hline $\mathrm{DA} 2 / 99 / 46$ & WNW of Rocky Head, Enderby Island & $17.5-18.0$ & $20^{\circ} 35.90^{\prime} \mathrm{S}$ & $116^{\circ} 24.60^{\prime} \mathrm{E}$ \\
\hline $\mathrm{DA} 2 / 99 / 47$ & $\mathrm{~N}$ of W of Rocky Head, Enderby Island & $20.0-22.5$ & $20^{\circ} 36.58^{\prime} \mathrm{S}$ & $116^{\circ} 23.66^{\prime} \mathrm{E}$ \\
\hline DA2 $/ 99 / 48$ & S of W of Rocky Head, Enderby Island & $20.5-21.0$ & $20^{\circ} 37.43^{\prime} \mathrm{S}$ & $116^{\circ} 24.08^{\prime} \mathrm{E}$ \\
\hline $\mathrm{DA} 2 / 99 / 49$ & $S$ of $W$ of $W$ tip of Eaglehawk Island & $15.5-16.0$ & $20^{\circ} 40.30^{\prime} \mathrm{S}$ & $116^{\circ} 22.59^{\prime} \mathrm{E}$ \\
\hline $\mathrm{DA} 2 / 99 / 50$ & W of Rocky Head, Enderby Island & $24.0-25.0$ & $20^{\circ} 37.10^{\prime} \mathrm{S}$ & $116^{\circ} 20.99^{\prime} \mathrm{E}$ \\
\hline $\mathrm{DA} 2 / 99 / 51$ & W of SW point of Goodwyn Island & $31.4-31.5$ & $20^{\circ} 32.40^{\prime} \mathrm{S}$ & $116^{\circ} 24.19^{\prime} \mathrm{E}$ \\
\hline $\mathrm{DA} 2 / 99 / 52$ & W of SW tip of Goodwyn Island & $31.2-32.3$ & $20^{\circ} 31.85^{\prime} \mathrm{S}$ & $116^{\circ} 21.48^{\prime} \mathrm{E}$ \\
\hline $\mathrm{DA} 2 / 99 / 53$ & WNW of NW point of Goodwyn Island & $32.0-34.0$ & $20^{\circ} 30.90^{\prime} \mathrm{S}$ & $116^{\circ} 26.05^{\prime} \mathrm{E}$ \\
\hline $\mathrm{DA} 2 / 99 / 54$ & WNW of NW point of Goodwyn Island & $36.0-37.0$ & $20^{\circ} 29.31^{\prime} \mathrm{S}$ & $116^{\circ} 25.18^{\prime} \mathrm{E}$ \\
\hline $\mathrm{DA} 2 / 99 / 55$ & NW of Roly Rock & $37.5-38.0$ & $20^{\circ} 28.45^{\prime} S$ & $116^{\circ} 27.43^{\prime} \mathrm{E}$ \\
\hline $\mathrm{DA} 2 / 99 / 56$ & W of Roly Rock & 34.5 & $20^{\circ} 30.10^{\prime} \mathrm{S}$ & $116^{\circ} 28.27^{\prime} \mathrm{E}$ \\
\hline $\mathrm{DA} 2 / 99 / 57$ & N of Roly Rock & $32.0-33.0$ & $20^{\circ} 29.03^{\prime} \mathrm{S}$ & $116^{\circ} 30.45^{\prime} \mathrm{E}$ \\
\hline $\mathrm{DA} 2 / 99 / 58$ & NNE of Roly Rock & $25.0-25.5$ & $20^{\circ} 29.11^{\prime} \mathrm{S}$ & $116^{\circ} 30.78^{\prime} \mathrm{E}$ \\
\hline $\mathrm{DA} 2 / 99 / 59$ & S of Courtenay Head Light, Malus Island & $17.0-19.0$ & $20^{\circ} 32.23^{\prime} \mathrm{S}$ & $116^{\circ} 41.63^{\prime} \mathrm{E}$ \\
\hline $\mathrm{DA} 2 / 99 / 60$ & ESE of Courtenay Head Light, Malus Island & $16.0-17.0$ & $20^{\circ} 31.38^{\prime} \mathrm{S}$ & $116^{\circ} 44.24^{\prime} \mathrm{E}$ \\
\hline $\mathrm{DA} 2 / 99 / 61$ & NW of Philip Point, Burrup Peninsula & 11.0 & $20^{\circ} 35.33^{\prime} \mathrm{S}$ & $116^{\circ} 42.78^{\prime} \mathrm{E}$ \\
\hline $\mathrm{DA} 2 / 99 / 62$ & Flying Foam Passage, NE of S tip of Angel Island & $7.0-9.0$ & $20^{\circ} 30.69^{\prime} \mathrm{S}$ & $116^{\circ} 48.58^{\prime} \mathrm{E}$ \\
\hline $\mathrm{DA} 2 / 99 / 63$ & NNE of light on East Intercourse Island & $11.5-12.0$ & $20^{\circ} 38.35^{\prime} \mathrm{S}$ & $116^{\circ} 41.23^{\prime} \mathrm{E}$ \\
\hline $\mathrm{DA} 2 / 99 / 64$ & $\mathrm{~N}$ of light on East Intercourse Island & $12.0-14.0$ & $20^{\circ} 37.43^{\prime} \mathrm{S}$ & $116^{\circ} 40.77^{\prime} \mathrm{E}$ \\
\hline $\mathrm{DA} 2 / 99 / 65$ & NW of light on East intercourse Island & $10.0-15.0$ & $20^{\circ} 38.31^{\prime} \mathrm{S}$ & $116^{\circ} 38.46^{\prime} \mathrm{E}$ \\
\hline
\end{tabular}




\begin{tabular}{|c|c|c|c|c|}
\hline Station & Location & Depth (m) & Latitude & Longitude \\
\hline DA2/99/66 & ESE of Bluff Point, Enderby Island & $7.2-7.5$ & $20^{\circ} 38.40^{\prime} \mathrm{S}$ & $116^{\circ} 35.66^{\circ} \mathrm{E}$ \\
\hline $\mathrm{DA} 2 / 99 / 67$ & SSE of Bluff Point, Enderby Island & 10.5 & $20^{\circ} 39.11 \mathrm{~S}$ & $116^{\circ} 33.98^{\prime} \mathrm{E}$ \\
\hline DA2/99/68 & S of Bluff Point, Enderby Island & $9.0-9.2$ & $20^{\circ} 40.93 \mathrm{~S}$ & $116^{\circ} 33.21^{\prime} \mathrm{E}$ \\
\hline $\mathrm{DA} 2 / 99 / 69$ & SE of SE point of Goodwyn Island & $11.5-14.0$ & $20^{\circ} 34.34 \mathrm{~S}$ & $116^{\circ} 34.67^{\prime} \mathrm{E}$ \\
\hline $\mathrm{DA} 2 / 99 / 70$ & SSW of Bluff Point, Enderby Island & 10.0 & $20^{\circ} 41.45^{\prime} \mathrm{S}$ & $116^{\circ} 30.78^{\prime} \mathrm{E}$ \\
\hline $\mathrm{DA} 2 / 99 / 71$ & S of Rocky Head, Enderby Island & 10.5 & $20^{\circ} 41.49^{\prime} \mathrm{S}$ & $116^{\circ} 28.05^{\prime} \mathrm{E}$ \\
\hline $\mathrm{DA} 2 / 99 / 72$ & SSW of Rocky Head, Enderby Island & 10.0 & $20^{\circ} 42.13^{\prime} \mathrm{S}$ & $116^{\circ} 26.22^{\prime} \mathrm{E}$ \\
\hline $\mathrm{DA} 2 / 99 / 73$ & S of Rocky Head, Enderby Island & 12.5 & $20^{\circ} 40.14 \mathrm{~S}$ & $116^{\circ} 27.69^{\prime} \mathrm{E}$ \\
\hline $\mathrm{DA} 2 / 99 / 74$ & SE of Rocky Head, Enderby Island & $10.5-11.5$ & $20^{\circ} 38.34 \mathrm{~S}$ & $116^{\circ} 29.18^{\prime} \mathrm{E}$ \\
\hline DA2/99/75 & E of NE Point of Goodwyn Island & $14.0-19.0$ & $20^{\circ} 32.16^{\prime} \mathrm{S}$ & $116^{\circ} 33.70^{\prime} \mathrm{E}$ \\
\hline $\mathrm{DA} 2 / 99 / 76$ & W of NW point of Goodwyn Island & $13.0-15.0$ & $20^{\circ} 32.11^{\prime} \mathrm{S}$ & $116^{\circ} 31.55^{\prime} \mathrm{E}$ \\
\hline $\mathrm{DA} 2 / 99 / 77$ & NW of NW point of Goodwyn Island & $13.0-14.0$ & $20^{\circ} 30.57 \mathrm{~S}$ & $116^{\circ} 30.89^{\prime} \mathrm{E}$ \\
\hline $\mathrm{DA} 2 / 99 / 78$ & NE of NW Point of Goodwyn Island & $14.0-15.0$ & $20^{\circ} 31.09^{\prime} \mathrm{S}$ & $116^{\circ} 33.04^{\prime} \mathrm{E}$ \\
\hline $\mathrm{DA} 2 / 99 / 79$ & WNW of $W$ end of Kendrew Island & 38.0 & $20^{\circ} 27.64 \mathrm{~S}$ & $116^{\circ} 29.54^{\prime} \mathrm{E}$ \\
\hline DA2/99/81 & $N$ of $W$ end of Kendrew Island & 38.0 & $20^{\circ} 26.51 \mathrm{~S}$ & $116^{\circ} 31.57^{\prime} \mathrm{E}$ \\
\hline $\mathrm{DA} 2 / 99 / 82$ & $N$ of $N$ point of Kendrew Island & $32.0-36.0$ & $20^{\circ} 27.57 \mathrm{~S}$ & $116^{\circ} 32.35^{\prime} \mathrm{E}$ \\
\hline $\mathrm{DA} 2 / 99 / 83$ & ENE of NE point of Goodwyn Island & $11.5-11.7$ & $20^{\circ} 31.60 \mathrm{~s}$ & $116^{\circ} 36.19^{\prime} \mathrm{E}$ \\
\hline $\mathrm{DA} 2 / 99 / 84$ & E of Tish Point, Rosemary lsland & $12.5-15.0$ & $20^{\circ} 29.94 \mathrm{~S}$ & $116^{\circ} 38.11^{\prime} \mathrm{E}$ \\
\hline DA2/99/85 & E of E point of Brigadier Island & $28.0-29.0$ & $20^{\circ} 26.38^{\prime} \mathrm{S}$ & $116^{\circ} 39.76^{\prime} \mathrm{E}$ \\
\hline $\mathrm{DA} 2 / 99 / 87$ & ENE of E point of Brigadier Island & $33.0-33.5$ & $20^{\circ} 25.48^{\prime} \mathrm{S}$ & $116^{\circ} 39.07 \mathrm{E}$ \\
\hline $\mathrm{DA} 2 / 99 / 88$ & $N$ of $W$ point of Brigadier Island & $33.5-38.5$ & $20^{\circ} 26.04^{\prime} \mathrm{S}$ & $116^{\circ} 36.77^{\prime} \mathrm{E}$ \\
\hline $\mathrm{DA} 2 / 99 / 89$ & N of Gordon Point, Rosemary Island & $27.0-28.0$ & $20^{\circ} 27.33^{\prime} \mathrm{S}$ & $116^{\circ} 34.39^{\prime} \mathrm{E}$ \\
\hline DA2/99/90 & $N$ of Gordon Point, Rosemary Island & 38.0 & $20^{\circ} 25.68^{\prime} \mathrm{S}$ & $116^{\circ} 33.96{ }^{\prime} \mathrm{E}$ \\
\hline $\mathrm{DA} 2 / 99 / 91$ & ESE of Tish Point, Rosemary Island & $9.0-10.0$ & $20^{\circ} 30.48^{\prime} \mathrm{S}$ & $116^{\circ} 36.53^{\prime} \mathrm{E}$ \\
\hline $\mathrm{DA} 2 / 99 / 92$ & NE of Bluff Point, Enderby Island & 17.0 & $20^{\circ} 34.64 ' S$ & $116^{\circ} 35.74^{\prime} \mathrm{E}$ \\
\hline $\mathrm{DA} 2 / 99 / 93$ & SE of King Point, East Lewis Island & $12.0-13.0$ & $20^{\circ} 38.29^{\prime} \mathrm{S}$ & $116^{\circ} 38.39^{\prime} \mathrm{E}$ \\
\hline $\mathrm{DA} 2 / 99 / 94$ & SE of King Point, East Lewis Island & $14.5-16.0$ & $20^{\circ} 38.37^{\prime} \mathrm{S}$ & $116^{\circ} 38.41^{\prime} \mathrm{E}$ \\
\hline $\mathrm{DA} 2 / 99 / 95$ & W of Bluff Point, Enderby Island & $5.0-7.0$ & $20^{\circ} 37.37 \mathrm{~S}$ & $116^{\circ} 31.69^{\prime} \mathrm{E}$ \\
\hline $\mathrm{DA} 2 / 99 / 96$ & W of Bluff Point, Enderby Island & 9.0 & $20^{\circ} 37.50^{\prime} \mathrm{S}$ & $116^{\circ} 31.56^{\prime} \mathrm{E}$ \\
\hline $\mathrm{DA} 2 / 99 / 98$ & SSW of Bluff Point, Enderby Island & $10.5-11.0$ & $20^{\circ} 39.81^{\prime} \mathrm{S}$ & $116^{\circ} 31.92^{\prime} \mathrm{E}$ \\
\hline $\mathrm{DA} 2 / 99 / 99$ & WSW of Rocky Head, Enderby Island & $17.0-19.0$ & $20^{\circ} 37.36^{\prime} \mathrm{S}$ & $116^{\circ} 26.85^{\prime} \mathrm{E}$ \\
\hline
\end{tabular}




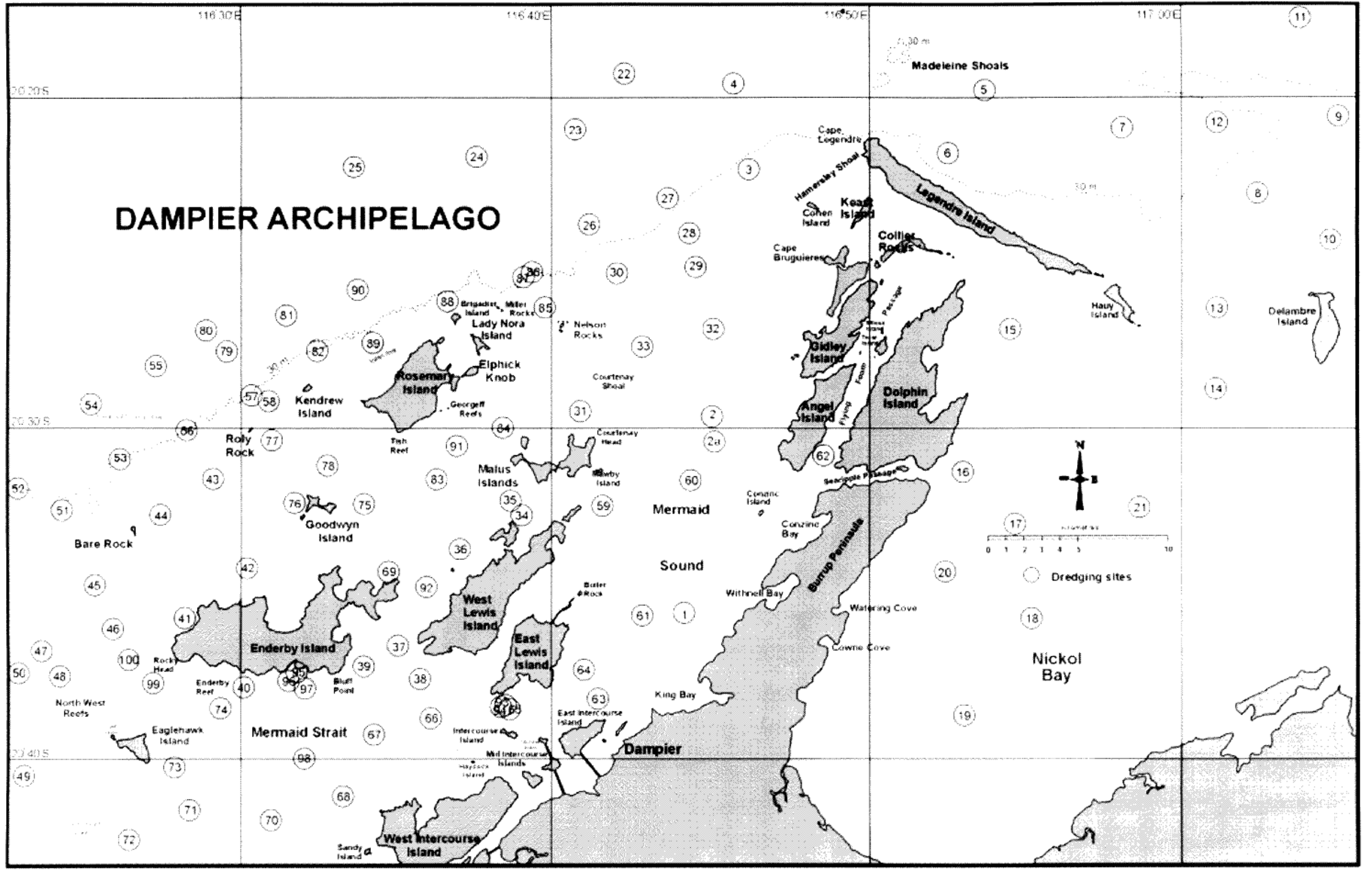


Appendix 8 Locations, latitudes and longitudes of stations from workshop expedition DA4/00.

\begin{tabular}{lllll}
\hline Station & Location & Depth (m) & Latitude & Longitude \\
\hline DA4/00/01 & W side Angel Island & 4.0 & $20^{\circ} 29.05^{\prime} \mathrm{S}$ & $116^{\circ} 47.83^{\prime} \mathrm{E}$ \\
DA4/00/03 & NW West Lewis Island & Intertidal & $20^{\circ} 33.52^{\prime} \mathrm{S}$ & $116^{\circ} 38.21^{\prime} \mathrm{E}$ \\
DA4/00/04 & SW tip West Lewis Island & 5.6 & $20^{\circ} 36.17 ' \mathrm{~S}$ & $116^{\circ} 35.74^{\prime} \mathrm{E}$ \\
DA4/00/06 & SW Lewis Island & 8.6 & $20^{\circ} 26^{\prime} .25^{\prime} \mathrm{S}$ & $116^{\circ} 35.71^{\prime} \mathrm{E}$ \\
DA4/00/08 & SW Lewis Island & 5.8 & $20^{\circ} 36.31^{\prime} \mathrm{S}$ & $116^{\circ} 35.70^{\prime} \mathrm{E}$ \\
DA4/00/09 & Between Enderby \& West Lewis Islands & 17.7 & $20^{\circ} 35.12^{\prime} \mathrm{S}$ & $116^{\circ} 35.63^{\prime} \mathrm{E}$ \\
DA4/00/10 & W side Enderby Island near Rocky Point & 11.2 & $20^{\circ} 35.39^{\prime} \mathrm{S}$ & $116^{\circ} 28.57^{\prime} \mathrm{E}$ \\
DA4/00/12 & Nelson Rocks & 20.1 & $20^{\circ} 26.51^{\prime} \mathrm{S}$ & $116^{\circ} 40.26^{\prime} \mathrm{E}$ \\
DA4/00/14 & NW end Legendre Island & 12.3 & $20^{\circ} 21.21^{\prime} \mathrm{S}$ & $116^{\circ} 50.44^{\prime} \mathrm{E}$ \\
DA4/00/15 & NW end Legendre Island & 16.0 & $20^{\circ} 21.21^{\prime} \mathrm{S}$ & $116^{\circ} 50.44^{\prime} \mathrm{E}$ \\
DA4/00/16 & Mid north shore Legendre Island & 16.0 & $20^{\circ} 24.03^{\prime} \mathrm{S}$ & $116^{\circ} 55.08^{\prime} \mathrm{E}$ \\
DA4/00/17 & NW corner Conzinc Island & $20^{\circ} 31.90^{\prime} \mathrm{S}$ & $116^{\circ} 46.49^{\prime} \mathrm{E}$ \\
DA4/00/18 & SW Dolphin Island in Sea Ripple Passage & Intertidal & $20^{\circ} 31.01^{\prime} \mathrm{S}$ & $116^{\circ} 48.95^{\prime} \mathrm{E}$ \\
DA4/00/19 & Hearson's Cove & Intertidal & $20^{\circ} 37.62^{\prime} \mathrm{S}$ & $116^{\circ} 48.155^{\prime} \mathrm{E}$ \\
DA4/00/22 & Between Enderby \& West Lewis Islands & 19.0 & $20^{\circ} 35.11 ' \mathrm{~S}$ & $116^{\circ} 35.62^{\prime} \mathrm{E}$ \\
DA4/00/23 & NW corner Roly Rocks & 8.6 & $20^{\circ} 29.88^{\prime} \mathrm{S}$ & $116^{\circ} 30.05^{\prime} \mathrm{E}$ \\
DA4/00/27 & Enderby Island W of Rocky Head & 15.5 & $20^{\circ} 37.10^{\prime} \mathrm{S}$ & $116^{\circ} 26.722^{\prime} \mathrm{E}$ \\
DA4/00/39 & NE Corner Delambre Island & Intertidal & $20^{\circ} 25.71^{\prime} \mathrm{S}$ & $117^{\circ} 05.11 \mathrm{E}$ \\
DA4/00/41 & SSW Rocky Head Enderby Island & $11.0-13.0$ & $20^{\circ} 37.30^{\prime} \mathrm{S}$ & $116^{\circ} 27.38^{\prime} \mathrm{E}$ \\
\hline
\end{tabular}




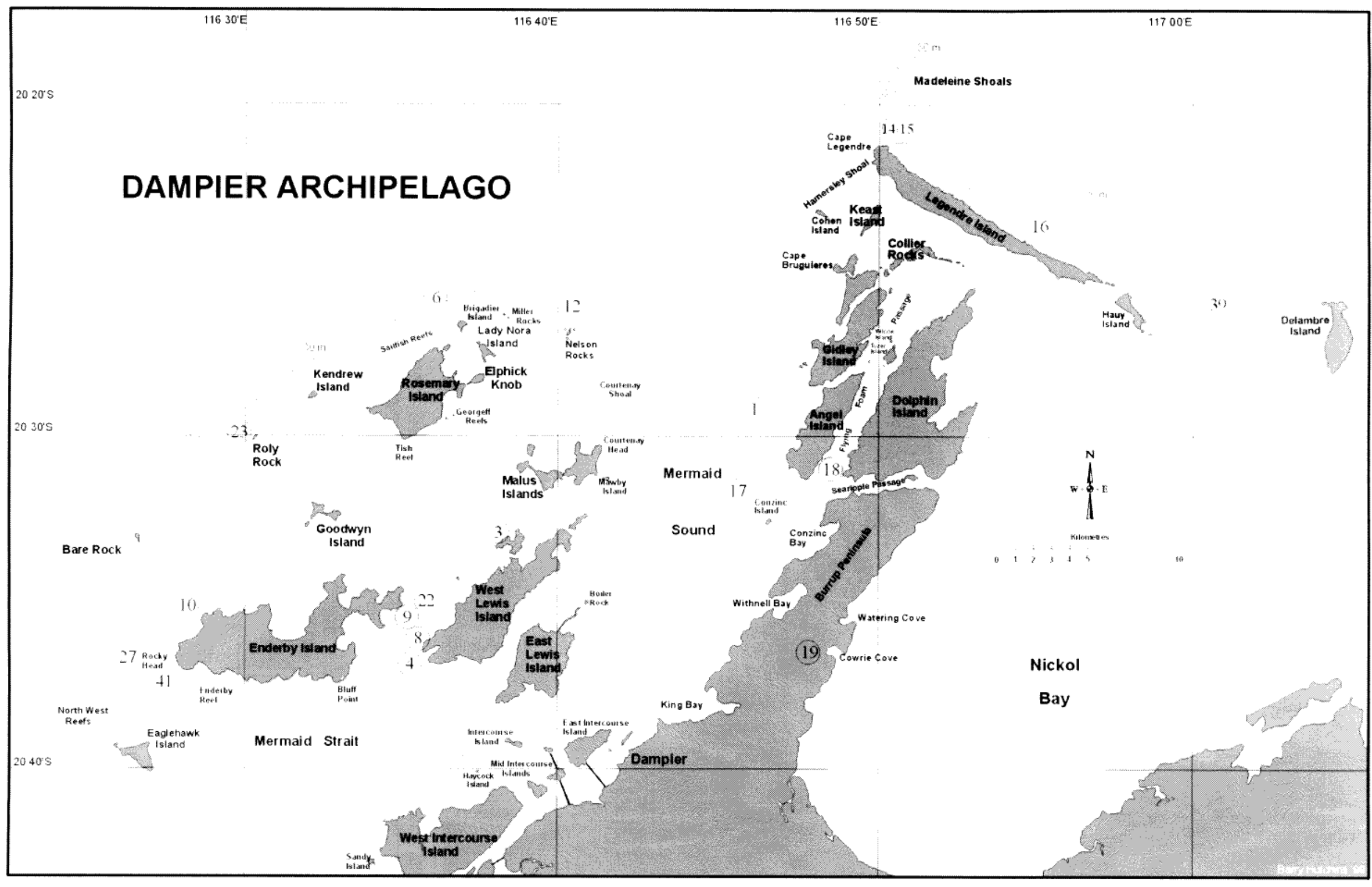

